\begin{abstract}
Universidade de São Paulo
Escola de Comunicação e Artes

Programa de Pós-graduação em Ciências da Informação Mestrado Profissional em Gestão da Informação
\end{abstract}

Denise Gomes Silva Morais Cavalcante

\title{
AUDIOVISUAL E WEB SEMÂNTICA: ESTUDO DE CASO DA BIBLIOTECA DA ECA
}

São Paulo

2018 


\section{AUDIOVISUAL E WEB SEMÂNTICA: ESTUDO DE CASO DA BIBLIOTECA DA ECA}

\section{Versão corrigida}

Dissertação apresentada ao Programa de Pós-Graduação em Ciência da Informação, Mestrado Profissional em Gestão da Informação, Universidade de São Paulo para obtenção do grau de Mestre em Ciências.

Área de Concentração: Organização, Mediação e Circulação da Informação

Orientador: Prof. Dr. Nair Yumiko Kobashi

São Paulo

2018 
Autorizo a reprodução e divulgação total ou parcial deste trabalho, por qualquer meio convencional ou eletrônico, para fins de estudo e pesquisa, desde que citada a fonte.

\author{
Catalogação na Publicação \\ Serviço de Biblioteca e Documentação \\ Escola de Comunicações e Artes da Universidade de São Paulo \\ Dados inseridos pelo(a) autor(a)
}

CAVALCANTE, Denise Gomes Silva Morais

AUDIOVISUAL $\mathrm{E}$ WEB SEMÂNTICA: ESTUDO DE CASO DA BIBLIOTECA

DA ECA / Denise Gomes Silva Morais CAVALCANTE ;

orientadora, Nair Yumiko Kobashi. -- Săo Paulo, 2018.

78 p.: il.

Dissertação (Mestrado Profissional) - Escola de

Comunicaçōes e Artes / Universidade de são Paulo.

Bibliografia

Versão corrigida

1. Imagem em movimento 2. Web Semântica 3. Linked Data

4. Biblioteca I. Yumiko Kobashi, Nair II. Título.

CDD 21.ed. - 020

Elaborado por Sarah Lorenzon Ferreira - CRB-8/6888 
Nome: CAVALCANTE, Denise Gomes Silva Morais

Título: Audiovisual e web semântica: estudo de caso da Biblioteca da ECA

Dissertação apresentada ao Programa de Pós-Graduação em Ciência da Informação, Mestrado Profissional em Ciências da Informação, Universidade de São Paulo para obtenção do grau de Mestre em Ciência da Informação.

Aprovado em: 10/01/2019

\section{Banca Examinadora}

Prof. Dra Nair Yumiko Kobashi (Presidente)

Instituição: Escola de Comunicação e Artes/USP

Julgamento:

Assinatura:

Prof Dra. Zaira Regina Zafalon

Instituição: UFSCar

Julgamento:

Assinatura:

Prof Dr Marcelo dos Santos

Instituição: Escola de Comunicação e Artes/USP

Julgamento:

Assinatura:

Prof Dra Joice Cleide Cardoso Ennes de Souza

Instituição: UFF

Julgamento:

Assinatura: 
Dedico aos meus pais por apoiar e motivar minha educação e conhecimento. 


\section{AGRADECIMENTOS}

Agradeço Deus por me permitir viver, indagar e refletir.

A minha mãe Eloiza e meu pai Edinilton, pelo apoio incondicional nesse percurso acadêmico, que são minha fortaleza e exemplo de pais e professores dedicados, aos meus irmãos Dalita e Danilo, meus amados sobrinhos Davi, Felipe e Gabriel. A vó Maria, vô José, a tia Carminha, o tio Vino, os primos Jaqueline, Vinicius e Livia, pelas orações e apoio familiar. Ao meu companheiro Marcos pelos cuidados e atenção. Minha eterna gratidão a todos vocês. Aos amigos e parentes, que mesmos distantes torcem pela minha caminhada. A Nair, minha orientadora pelo apoio, paciência e carinho, principalmente nos momentos difíceis, que me orientou, com atenção e dedicação, nos últimos dois anos nas pesquisas acadêmicas e me auxiliou na vida pessoal. Muito grata, professora Nair. Aos professores Marcelo Santos, Asa Fujino que contribuíram durante o desenvolvimento das pesquisas acadêmicas com apontamentos e reflexões valiosas para a dissertação. Aos bibliotecários da ECA, em especial Marina Macambyra pela gentileza de me receber, auxiliar e conversar sobre o trabalho de catalogação de filmes da ECA. A Universidade de São Paulo, especialmente ao Programa de Pós-graduação em Ciências da Informação, que me deu todas as bases acadêmicas para assimilar os conceitos de $\mathrm{Cl}$ de forma interdisciplinar. Aos funcionários do Departamento de Biblioteconomia e do PPGCI sempre prontos a atender e auxiliar. Aos colegas de curso e professores do PPGCl que ajudaram na minha formação durantes as disciplinas, seminários e trocas de conhecimento. 


\section{Resumo}

A navegação e recuperação entre recursos de catálogos diferentes através de tecnologias Linked Data e da web semântica pode diminuir a sobrecarga para gestão, interoperabilidade e compartilhamento de dados como forma de cooperação institucional, além disso ser modo diferente de navegação entre acervos de instituições e ambientes informacionais externos, possibilitando novas formas de consulta de dados. O objetivo da pesquisa é apresentar uma proposta com um conjunto de indicativos para preparar instrumentos de recuperação de filmes universitários da biblioteca da ECA dentro do contexto do linked data. Dessa forma, a metodologia inclui a revisão de literatura da área para estudo do estado da arte e o levantamento de tecnologias da web semântica que visam a criação de padrões de metadados, vocabulários, ontologias e modelos conceituais voltados a anotação e descrição audiovisual, assim como uma parte empírica com estudo de caso do catálogo e do manual de filmes da Biblioteca da ECA.

Palavras-Chave: Linked data; Audiovisual, Web Semântica; Biblioteca; Arquivo Fílmico Universitário. 


\section{ABSTRACT}

The navigation and retrieval between different catalog resources through Linked Data and semantic web technologies can reduce the overhead for management, interoperability and data sharing as a form of institutional cooperation, besides being a different way of navigating between collections of institutions and informational environments new ways of querying data. The objective of this research is to identify the instruments and methodologies of descriptive, thematic representation and retrieval of audiovisual documents in the context of libraries, phylogenies and the semantic web. Thus, the methodology includes the review of the literature of the area for the study of the state of the art and the survey of semantic web technologies that aim at the creation of standards of metadata, vocabularies, ontologies and conceptual models aimed at annotation and audiovisual description, as well as an empirical part with a case study of the catalog and the film manual of the ECA Library.

Keywords: Linked Data; Moving picture; Semantic Web; Library; Film Archive. 


\section{Lista de Figuras}

Figura 1: Contagem do gênero dos filmes estrelados por um ator..........................................50

Figura 2: Músicos responsáveis pela trilha sonora de uma série de filmes.............................50

Figura 3: Usando o SKOS (Simple Knowledge Organization System) ou outro modelo para codificar vocabulários controlados como LOD...................................................................52

Figura 4: Codificação LOD de vocabulários em Glossários Filmográficos e Técnicos, para uso

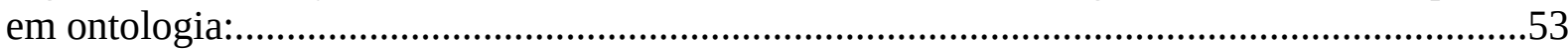

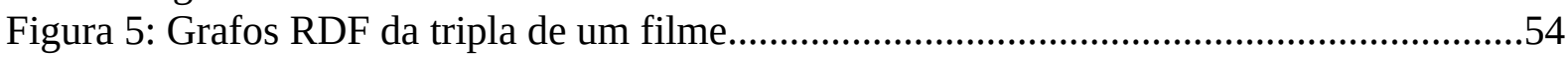

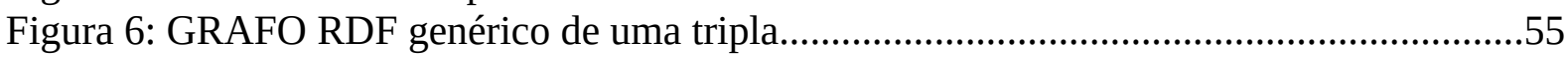

Figura 7: GRAFO RDF com três triplas de um mesmo recurso................................................53

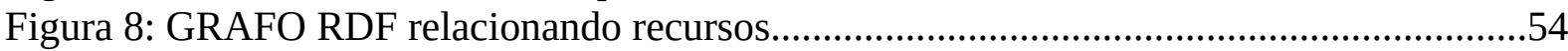

Figura 9: Representa ligações entre recursos que representam uma mesma informação..........54

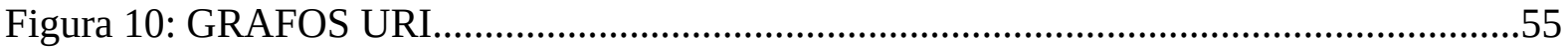

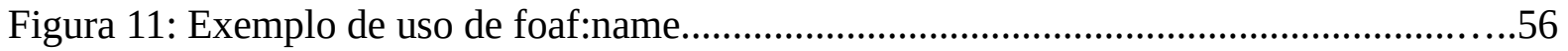

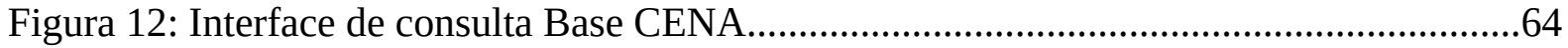

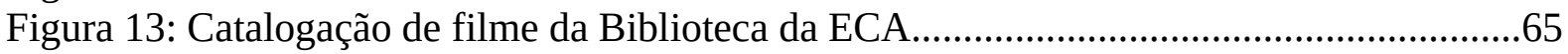

Figura 14: Mapeamento entre campos MARC e elementos Dublin Core...............................77

Figura 15: Resumo dos campos do manual de catalogação da biblioteca................................78 


\section{Lista de quadros}

Tabela 1: componentes da web semântica e do linked data: conteúdo de dados, estrutura, semântica e formato de intercâmbio. .42

Tabela 2: Tabela 2: Metadados e Vocabulários relevantes para o contexto multimídia............49

Tabela 3: Mapeamento dos campos do recurso da figura 13...............................................69 


\section{LISTA DE SIGLAS}

AACR - Anglo-American Cataloguing Rules

BIBFRAME - Bibliographic Framework

DC - Dublin Core

FIAF - International Federation of Film Archives

FRBR - Requirements for Bibliographic Records

IFLA - International Federation of Library Associations and Institutions

ISBD International Standard Bibliographic Description

LMDB- Linked Movie Data Base

LC - Library of Congress

OWL-Ontology Web Language

RDF - Resource Description Framework

RDA - Resource Descripton and Access

URI Uniform Resource Identifiers (URI)

W3C- World Wide Web Consorti 


\section{SUMÁRIO}

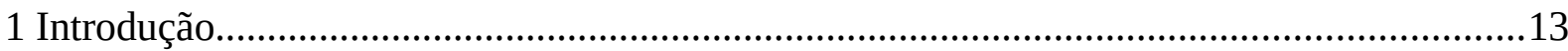

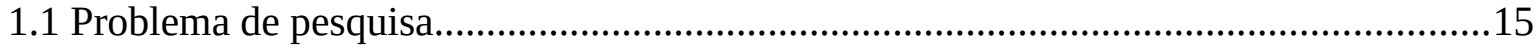

1.2 Hipótese de trabalho.................................................................................................18

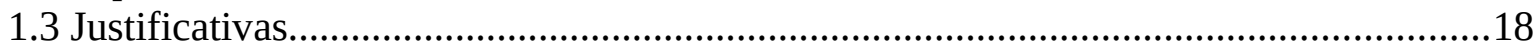

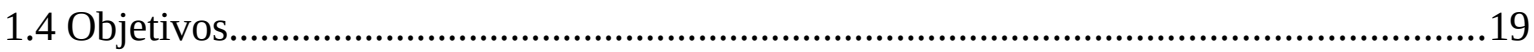

1.4.1 Objetivos Gerais.......................................................................................

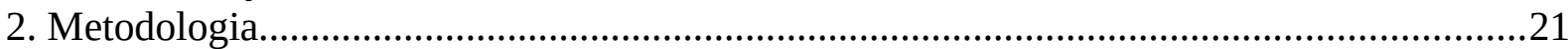

2.1 Parte teórica.....................................................................................................21

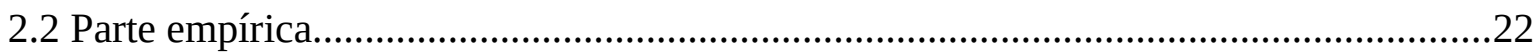

3. Representação temática e descritiva da informação..................................................................23

3.1 A representação temática no contexto da web semântica..................................................23

3.2 Representação descritiva no contexto da web semântica.................................................26

3.3 FIAF e a representação descritiva................................................................................35

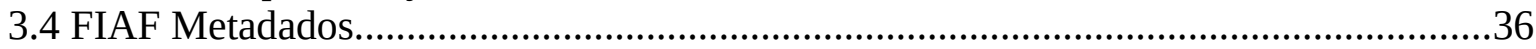

4 Web semântica e informação................................................................................................39

4.1 Web semântica...........................................................................................................39

4.2 Web semântica e informação audiovisual.........................................................................4

4.3 Audiovisual e Linked Data...................................................................................46

4.4 Projetos e iniciativas internacionais para audiovisual e Linked Data...............................57

5. Proposta: Organização de dados para recuperar informações sobre textos e arquivos de filmes universitários: uma aplicação ao acervo de TCCS do Curso de Audiovisual da

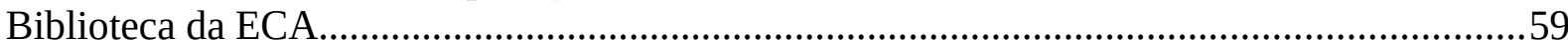

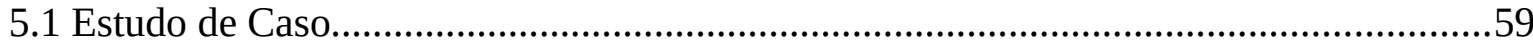

5.1.1 Descrição do objeto empírico: TCCS: Descrição do corpus (conjunto de documentos)........................................................................................................59

5.1.1.1 Recorte TCCs e Biblioteca da ECA (open biblioteca/ exemplo: acervo obras

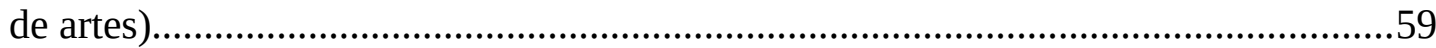

5.1.1.2 Metadados, formas de descrição e representação temática da Biblioteca da

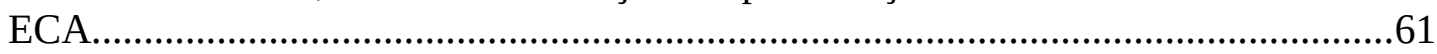

5.1.1.3 Coleta de dados e levantamento do material..................................................63

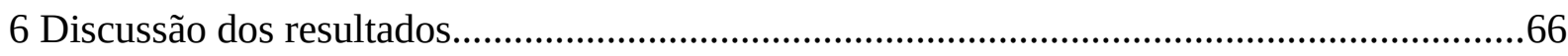

7 Considerações finais e pesquisas futuras...............................................................................71

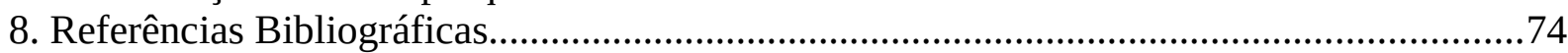




\section{Introdução}

A chamada explosão informacional e o desenvolvimento da internet atingiram todas as áreas do conhecimento e os efeitos disso são sentidos em diversos contextos sociais, como, por exemplo, nas metodologias de ensino, nas formas de acesso à informação, nas relações e estágios da comunicação científica, nos modos de fazer pesquisa, nas estratégias de marketing do mercado, no panorama de tratamento de informações jurídicas, na forma de consumo do entretenimento, na fruição dos bens e produtos culturais, entre muitas outras áreas.

Dentro do escopo de estudos da Ciência da Informação essas mudanças requerem reflexões sobre os modos de produzir, registrar, tratar, representar, organizar e recuperar o conhecimento gerado pela humanidade. Nesse contexto, muitos suportes dos registros do conhecimento foram atualizados em formatos digitais e é possível destacar que a mudança mais significativa ocorrida nesse novo cenário é a desterritorialização do documento, sua desassociação das formas físicas analógicas, como a materialidade do papel e da película fílmica: digitalização dos recursos possibilitou a organização, num mesmo espaço, de textos, imagens, sons e índices, muitos deles também em forma hipertextual (ALVARENGA, 2003). Essas mudanças físicas na materialidade dos objetos que são produtos do conhecimento humano alteraram os modos de representação primária de registros de conhecimentos e a representação secundária nos sistemas de informações documentais, outra mudança significativa provocada pela internet, que se relaciona com a materialidade do documento estar dissociada do suporte analógico, é que sua representação e o documento digital não estão mais em espaços separados, muitas vezes, o documento e sua representação estão no interior do mesmo sistema, isto é, os metadados são adjacentes ao documento (ALVARENGA, 2003).

Desde a metade do século XX, o compartilhamento de dados entre as instituições, ganhou força por meio da interoperabilidade e disponibilização de catálogos na web. "A interoperabilidade entre sistemas de acervos sempre estiveram baseadas na troca de metadados, na sua agregação em uma base de dados comum e na operação desta base por programas gerenciadores de catálogos" (MARCONDES, 2016, p. 64). Atualmente, a discussão sobre a interoperabilidade e a integração de acervos de diferentes instituições como arquivos, museus e bibliotecas está centrada nas tecnologias da web semântica e de dados abertos interligados. Segundo Marcondes (2016) a integração de acervos diretamente na web, sem a necessidade de programas gerenciadores de catálogos, 
ocorre através de links semânticos que exploram o significado da ligação entre diferentes recursos, ou seja, links que são significativos para programas. Para isso, são utilizados o linked data e padrões da Web Semântica, como o RDF e URI e a publicação de conjuntos de dados estruturados, separados por 9 categorias que são constantemente atualizadas chamados datasets, as informações presentes nesses datasets são caracterizadas na maior parte como informação textual.

A presente pesquisa analisa os desafios em relação aos recursos audiovisuais, pois, a representação descritiva e a representação temática são dificultadas pelos aspectos intrínsecos ao conteúdo audiovisual (SILVA, 2016; BARRETO, 2009; GRISOTO, 2016). Visto que, um documento audiovisual não existe separado da noção de informação, ele é sempre intencional, registrado em suporte e recuperável (SMIT, 2012), ele se difere das características do texto. E assim como os outros tipos de informação, que antes tinham suportes diferentes (papel, película, filme fotográfico, fita magnética), a informação audiovisual no contexto digital pode compartilhar o mesmo espaço de registro e representação com outros recursos informacionais (bibliográficos, textuais, imagéticos, sonoros).

Os datasets que contêm recursos audiovisuais são denominados Mídia e referemse em sua maioria à informação sobre música e não necessariamente ao recurso audiovisual. Segundo Grisoto (2016), uma análise desses conjuntos publicados de dados abertos apresentou dificuldade em encontrar exemplos de descrição de recursos audiovisuais em RDF/XML.

Smit (1993) comenta que no campo da Ciência da Informação o documento audiovisual era um objeto de conhecimento distante das instituições como Museus, Arquivos e Bibliotecas, com pouca bibliografia e sem um corpus teórico estruturado; entretanto, o contexto que a autora descreve faz referência ao cenário de 24 anos atrás. Atualmente, para se ter uma melhor definição do campo em relação à informação audiovisual é preciso fazer uma revisão do estado da arte.

Como no escopo desta pesquisa está a Organização da Informação de documentos e recursos audiovisuais, é necessário que os registros e documentos sejam analisados sob a perspectiva e características da informação audiovisual. As especificidades dos Requirements for Bibliographic Records (FRBR), por exemplo, analisado sob a perspectiva de um arquivo fílmico de uma cinemateca, terá suas entidades, atributos e relacionamentos adaptados para aquele tipo de informação. Segundo o manual da International Federation of Film Archives (FIAF), os modelos 
escolhidos para definir as entidades do grupo 1 Obra, Expressão, Manifestação e Item, são diferentes dos modelos usados para uma informação bibliográfica (FIAF, 2016).

Para o desenvolvimento da pesquisa, escolhemos como objeto de estudo de caso o acervo de filmes da Biblioteca da ECA, abordando o contexto geral do acervo, mas com recorte principal no acervo de filmes que a forma o catálogo de TCCs audiovisuais dos cursos da ECA, isto é, os Trabalhos de Conclusão de Curso ECA/USP.

\subsection{Problema de pesquisa}

A digitalização da informação e sua separação do suporte analógico tradicional criou a possibilidade de juntar diferentes tipos de informação em um mesmo espaço, seja texto, áudio ou imagem, de forma linear ou hipertextual, fazendo com que a representação dos documentos não esteja separada daquilo que representa, ou seja, os metadados ficam inseridos junto a esses documentos. Isso possibilitou novas formas de compartilhar e recuperar documentos e objetos digitais, assim como a publicação e integração de acervos na Web.

Atualmente o documento audiovisual está presente em acervos de diferentes instituições de memória, como a Biblioteca do Congresso dos Estados Unidos ${ }^{1}$, Cinemateca Brasileira ${ }^{2}$, que preserva os acervos de arquivos fílmícos e bibliográficos; a Fundação Nacional das Artes (FUNARTE) ${ }^{3}$, que salvaguarda material em vídeo e uma coleção sobre o cinema brasileiro; há, ainda, o Museu da imagem e Som (MIS) ${ }^{4}$ que possui acervos Arquivísticos, Museológicos e Bibliográficos. Além disso, o documento audiovisual está presente em muitos outros espaços sociais, sob a forma de documentos históricos, ativos comerciais de empresas de entretenimento e organizações de notícias. Por outro lado, há escassez de estudos dentro da Ciência da Informação que tenham explorado em profundidade a informação, obras, documentos e acervos em formato audiovisual, no contexto da web.

Segundo Gracy (2018, p. 355, tradução nossa) inúmeras informações valiosas sobre criadores, locais, eventos, tópicos, características de objetos e ações institucionais não são suficientemente representadas ou as conexões possíveis de serem feitas ficam presas nos registros dos recursos e documentos audiovisuais e que muitas vezes essas informações são encontradas apenas por descoberta acidental. Segundo Gracy (2018) na

\footnotetext{
https://pt.wikipedia.org/wiki/Biblioteca_do_Congresso

http://cinemateca.gov.br/

http://www.funarte.gov.br/

http://www.mis-sp.org.br/
} 
catalogação de imagem em movimento falta semântica ao conjunto de campos, que ele chama de bits de informação e provoca a falta de acesso à informações ocultas em registros descritivos. Desse modo, o linked data (LD) seria uma possibilidade de conectar informações relevantes sobre essas mesmas entidades em outros conjuntos de dados e fontes de informação: "Se tais informações fossem semanticamente definidas e disponibilizadas como dados abertos, esses sistemas de informação poderiam ser o ponto de entrada e o ponto de encontro para um universo de conhecimento sobre a produção, exibição, preservação e uso da imagem em movimento". De acordo com Simionato et al (2018, p. 300), os dados disponibilizados nos catálogos ou sites temáticos são uma pequena parte do que a produção cinematográfica gera e com os princípios linked data, os dados dos recursos audiovisuais podem melhorar e oferecer outras formas mais desenvolvidas de uso e reuso dos recursos audiovisuais.

A proposta da Web Semântica de Berners-Lee, Hendler e Lassila (2001), cita que agentes computacionais podem fazer conexões e relações entre as informações, sem a necessidade de um catálogo fechado (MARCONDES, 2016) e sem o usuário navegar por diversas páginas fazendo a coleta individual e manual dos dados, sendo possível coletar e comparar dados em um único ambiente (SIMIONATO et al., 2018, p. 305).

Para o desenvolvimento desta pesquisa analisaremos os trabalhos de conclusão de curso de alunos da ECA/USP dos cursos de audiovisual, Jornalismo e Artes Visuais, que fazem parte do catálogo intitulado Trabalhos de Conclusão de Curso ECA/USP e segundo informação impressa no catálogo estão listados trabalhos de conclusão de curso de alunos da ECA/USP realizados em forma de reportagens, filmes, videoarte e outras formas de linguagem audiovisual. A totalidade do acervo de filmes, vídeos e DVDs está registrada em bases de dados online: Dédalus ${ }^{5}$ - Banco de Dados Bibliográficos da USP, catálogo de todas as bibliotecas da USP que ainda não traz a totalidade do acervo audiovisual da ECA e a base CENA $^{6}$ de Filmes e Vídeos, catálogo específico desse acervo, completo, disponível no site da Biblioteca da ECA.

Segundo o manual de catalogação de filmes da ECA (MACAMBYRA, 2009, p. 1) o acervo de imagens em movimento da Biblioteca da ECA/USP é formado por diferentes tipos de documentos: filmes importantes do cinema nacional e internacional; produções dos alunos do Curso Superior de Audiovisual da ECA; teses e trabalhos de conclusão de curso; óperas e outros documentos musicais, filmes publicitários; trabalhos de videoarte;

http://dedalus.usp.br/

http://www.eca.usp.br/biblioteca-bases/cena/search.htm 
programas de televisão; documentários que abordam assuntos relacionados às áreas de estudo da Escola e de apoio às atividades de ensino e pesquisa.

Através de pesquisa in loco verificou-se que o acervo audiovisual da Biblioteca da ECA é organizado por catálogos temáticos que podem ser acessados na biblioteca para consulta sobre a obra e o item. Os catálogos de filmes são organizados pelos seguintes temas: Dança, Ópera, Futebol, Documentários de Arte, Filmes acessíveis (audiodescrição e closed caption), Mostra Exploratória do Acervo de DVDs, Mulheres, Ficção Científica, São Paulo em filmes, Consciência Negra, Educação, Vingança, Trabalho e Trabalhadores, Revoluções, Filmes Japoneses, Corporalidade, ANCINE, Série Nacionais, Comédia, Animação, Viagens, Terror, Filmes Legais, 65 Filmes Dirigidos por Mulheres, Filmes Premiados do Curso de Audiovisual e Trabalhos de Conclusão de Curso ECA/USP.

De acordo a Macambyra (2009) o tratamento da informação do acervo teve início em 1981 junto com a Filmoteca do Departamento de Cinema, Rádio e Televisão que era ligado à Biblioteca as práticas documentais, nascendo a demanda de criar um catálogo de filmes para atender as necessidades do público principal do acervo: profissionais, estudantes e pesquisadores de cinema, o que influenciou o desenvolvimento de normas locais de catalogação. O código Anglo-Americano de Catalogação - 2. ${ }^{a}$ edição (AACR2), padrão usado pela Biblioteca no tratamento de documentos textuais, não se adequou às questões específicas do tratamento de imagens em movimento, pois "filmes não são livros, e tratá-los como se o fossem não se resolve o problema". Ainda segundo Macambyra (2009), para a construção de um conjunto de regras, foram analisados os hábitos dos usuários e alguns exemplos de fichas de outros acervos de imagens em movimento, estudo, realizado em conjunto com os alunos da disciplina Multimeios, da professora Johanna Smit do curso de Biblioteconomia da ECA. "Com a publicação das regras de catalogação da Federação Internacional dos Arquivos do Filme (FIAF), no início da década de 1991, algumas das decisões iniciais foram avaliadas e adaptadas". Pelo fato das regras da FIAF na época serem direcionadas a arquivos elas foram parcialmente aplicadas.

Diante desse quadro, pergunta-se: a) quais são as conexões possíveis de realizar entre recursos externos e internos nos catálogos de filmes da ECA? b) Quais datasets ajudariam os usuários a encontrar e conectar informações desejadas com a ajuda de agentes computacionais? c) É possível fazer um alinhamento e um mapeamento do catálogo e da base de dados de filmes da ECA para os princípios da web de dados? d) Quais procedimentos metodológicos são necessários para adequar os instrumentos de 
representação temática e descritiva da biblioteca no conjunto de tecnologias e regras usadas na web semântica utilizando-se do manual de catalogação de filmes da ECA e preservando recursos locais pré-existentes?

\subsection{Hipótese de trabalho}

Hipótese de trabalho: a hipótese é que se realizado o alinhamento das normas locais da Biblioteca da ECA presente no Manual de Catalogação de Filmes da ECA e da Base CENA com os princípios da web semântica e linked data com estudos de demandas e comportamento dos usuários é possível estabelecer relações e criar links que não são possíveis de serem realizadas nas bases de dados atuais da biblioteca e o resultado da pesquisa proporcionaria a criação de um conjunto de indicativos para preparar instrumentos de recuperação de filmes universitários da biblioteca da ECA dentro do contexto do linked data.

\subsection{Justificativas}

A preocupação com as pesquisas sobre acervos audiovisuais de TCCs universitários surgiu durante o bacharelado no curso de Cinema da Universidade de Santa Catarina, onde desenvolvi o tema sobre as novas formas para a preservação, acesso e difusão de recursos audiovisuais digitais e na web, que tiveram como resultado uma iniciação científica sobre repositórios institucionais e documentos audiovisuais no contexto dos cursos de arte e o Trabalho de Conclusão de Curso com diagnóstico sobre o material acumulado sem tratamento da informação do curso de cinema da UFSC. Dessa forma, durante a realização das disciplinas, da iniciação científica e de atividades práticas foi possível constatar que existe uma forte relação entre o acesso à informação audiovisual e as Ciências da Informação. E assim como os outros tipos de informação, que antes tinham suportes diferentes (papel, película, filme fotográfico, fita magnética), a informação audiovisual no contexto digital pode compartilhar o mesmo espaço de registro e representação com outros recursos informacionais (bibliográficos, textuais, imagéticos, sonoros). Nessa perspectiva, a presente pesquisa tem objetivos teóricos e empíricos tendo como amostragem o acervo de objetos audiovisuais da Biblioteca da ECA/USP. A importância da presente pesquisa do ponto de vista teórico e metodológico é estudar as teorias, instrumentos e tecnologias sobre a representação e recuperação de informação audiovisual em ambiente web e levando em conta as demandas e possibilidades trazidas 
pela web semântica. Espera-se que este este estudo possibilite oferecer um instrumento que possa ser usado por outros arquivos universitários ou auxiliar as pesquisas sobre o tema, ou ainda, ajudar a organizar e recuperar acervos audiovisuais de instituições. Espera-se, ainda, que pesquisas futuras, que surgirão a partir desta, contribuam para adensar o cenário nacional e internacional de estudos sobre a área de web semântica e audiovisual.

A escolha da Biblioteca da ECA/USP nasceu do fato de ser um ambiente que é simultaneamente arquivo e biblioteca, isto é, ao mesmo tempo, em que arquiva o item, mas também disponibiliza para o usuário. O segundo fato é o trabalho avançado da biblioteca em relação à representação descritiva, ao modelo conceitual utilizado e por dar atenção ao conteúdo. O trabalho local feito pela biblioteca facilita e aprimora o alinhamento do catálogo para linked data (LD).

Desse modo, a construção de um ambiente web colaborativo para o catálogo de TCCs da ECA, pode ser visto como um instrumento de recuperação de informação audiovisual, mas também de novas formas de fazer pesquisa em acervos em ambientes digitais, novas formas colaborativas e participativas de publicação, uma ferramenta de ensino para professores e fonte de informação estruturada para pesquisadores.

Acreditamos que esta pesquisa contribuirá para a formulação de novas questões e abordagens dentro da linha da Organização da Informação em relação aos recursos audiovisuais no contexto da web e web semântica, que fazem parte de unidades e ambientes informacionais, como bibliotecas e arquivos educativos.

\subsection{Objetivos}

\subsubsection{Objetivos Gerais}

O objetivo da pesquisa é apresentar uma proposta com um conjunto de indicativos para preparar instrumentos de recuperação de filmes universitários da biblioteca da ECA dentro do contexto do linked data.

\subsubsection{Objetivos Específicos}

1) realizar um levantamento de iniciativas de criação de padrões de metadados, vocabulários, ontologias e modelos conceituais voltados ao domínio da descrição audiovisual e do linked data.

2) identificar instrumentos e metodologias de representação descritiva, temática e recuperação de documentos audiovisuais no contexto de arquivos fílmicos universitários; 
3) analisar instrumentos e metodologias sobre os dados abertos vinculados (linked open data) em arquivos de filmes e de bibliotecas;

4) mapear conjunto de instrumentos para alinhar o manual de filmes da ECA e a base de dados aos princípios do Linked Open Data;

5) revisar projetos que discutem questões referentes a migração do modelo conceitual FRBR e padrão MARC 21, entre outros para RDF; 


\section{Metodologia}

\subsection{Parte teórica}

Esta pesquisa é de natureza qualitativa, exploratória e aplicada, baseada na literatura científica sobre os temas linked data, Web Semântica e audiovisual. Sobre a pesquisa exploratória Gil (2002, p. 41) afirma: "[...] estas pesquisas têm como objetivo proporcionar maior familiaridade com o problema, com vistas a torná-lo mais explícito ou a constituir hipóteses. Pode-se dizer que estas pesquisas têm como objetivo principal o aprimoramento de ideias ou a descoberta de intuições". Além disso, também pertence ao grupo da pesquisa descritiva e possui uma parte empírica.

Sob essa ótica, primeiramente será feito um estudo do estado da arte em relação à representação temática e descritiva e suas ligações com recursos audiovisuais, analisando o desenvolvimento de técnicas de construção de tesauros, vocabulários, linguagens documentárias e assuntos no contexto da web semântica; como essas tecnologias atuam nas atuais pesquisas sobre a utilização da web semântica como forma de publicar acervos e como se dá a estruturação de conceitos que formam a organização do conhecimento na perspectiva do domínio audiovisual. Em seguida, será estudada a literatura sobre representação descritiva e como as normas, metadados e padrões estão evoluindo no sentido de buscar soluções para o contexto da web e tecnologias da informação e possíveis novas demandas dos usuários, fazendo paralelo com as especificidades dos recursos audiovisuais. Ainda na parte teórica serão revistos os conceitos de web semântica, linked data, ontologia, metadados, RDF, SKOS, OWL e SPARQL, assim como pesquisadas as bases de dados, os datasets na nuvem linked open data que se adequam aos objetivos da pesquisa.

Temos como referências metodológicas pesquisas que tratam a evolução e aplicação de normas, padrões bibliográficos como o MARC 21 e o RDA e o modelo conceitual FRBRI, assim como catálogos e manuais de catalogação de imagem em movimento, como a FIAF e publicação (Manual) da Biblioteca da ECA/USP e pesquisas de profissionais dessas instituições.

Ainda na parte teórica, serão pesquisados e analisados os conceitos de web semântica e linked data a partir dos princípios postulados pelo W3C. Para alcançar a chamada web semântica (web de dados ou web 3.0), Berners-Lee (2006 apud Silva, 2014, p.120) postulou quatro princípios para o paradigma linked data, propondo que todos os dados publicados na Web tornar-se-iam parte de um espaço único de dados globais, a 
saber: i) use URIs para dar nomes as coisas; ii) use HTTP URIs para que pessoas possam identificar esses nomes; iii) quando alguém identificar um URI, forneça informação útil usando padrões da Web Semântica, tais como RDF e SPARQL; e iv) inclua links para outras URIs, de modo a possibilitar a descoberta de mais coisas.

\subsection{Parte empírica}

A parte empírica terá como estudo de caso uma pesquisa aplicada ao acervo de filmes da Biblioteca da ECA, com foco maior no catálogo de TCCs dos cursos da ECA. Primeiramente será definido o recorte no acervo através de uma taxa de amostragem, depois será descrito o corpus definido na amostra o objeto empírico: Tipo (Monografia e audiovisual), período e suporte, Tamanho da amostragem, Metadados, formas de descrição, base de dados, representação temática, Análise de conteúdo e organização do material. Por fim, será apresentada uma proposta com um conjunto de indicativos para preparar instrumentos de recuperação de filmes universitários da biblioteca da ECA dentro do contexto do Linked Data. 


\section{Representação temática e descritiva da informação}

\subsection{A representação temática no contexto da web semântica}

A principal conexão da $\mathrm{Cl}$ com as propostas do W3C para a Web Semântica estão relacionadas com as práticas da representação descritiva e temática, dentro da linha de Organização de Informação. Dessa forma, é importante definir conceitos sobre representação descritiva e temática, como base de conhecimento na criação de ontologias. Estas questões são o ponto inicial de projetos que buscam alinhar formatos de descrição bibliográfica e/ou também a representação temática com novos instrumentos de modelagem, representação e organização de informação para criar relações (axiomas e inferências) que não podem ser manifestadas pelos atuais instrumentos de representação.

A representação temática refere-se à representação dos assuntos dos documentos para aproximá-los, tornando mais fácil a recuperação de materiais relevantes que dizem respeito a temas semelhantes (MAIMONE; SILVEIRA; TÁLAMO, 2011), ajudam na recuperação da informação a partir de pontos de acesso para estabelecer comunicação entre a linguagem natural do usuário e a terminologia pertencente a um domínio ou conhecimento específico. (CATARINO; CERVANTES; ANDRADE, 2015).

No contexto da Web Semântica, os "(vocabulários) são utilizados para definir termos (e seus relacionamentos) para descrever e representar uma área do conhecimento, ou para serem adotados numa aplicação específica" (W3C, 2012 apud CATARINO; CERVANTES; ANDRADE, 2015, p. 112). É importante destacar que os tesauros possuem uma grande tradição, pois, há décadas têm evoluído a partir dos aportes teóricos da área de Ciência da Informação e as ontologias se apresentam em estado ainda incipiente. Esse fato é a justificativa de se desenvolver ontologias a partir de tesauros, pois, eles podem servir como substratos teóricos para a construção de ontologias (BOCCATO; RAMALHO; FUJITA, 2008).

Ainda segundo Boccato, Ramalho e Fujita (2008) a construção de tesauros originase de campos científicos como a Terminologia e de diretrizes construídas por normas internacionais, que norteiam sua elaboração e torna viável a qualidade e a precisão na determinação dos termos/ descritores representativos de conceitos de um determinado domínio científico e podem ser representados de forma sistemática, já às ontologias provém da subárea de Inteligência Artificial, visando à criação e organização de bases de conhecimento computacionais e seu desenvolvimento se pauta principalmente em 
linguagens computacionais e não existem diretrizes ou normas de desenvolvimento consolidadas.

As práticas da representação descritiva e temática, dentro da linha de Organização de Informação, se conectam com as propostas do W3C para a Web Semântica com foco principal nas potencialidades de organização e recuperação de recursos informacionais por instituições e usuários. De modo que as consultas em base de dados possam ocorrer com recursos internos e externos aos catálogos, além de ser possível realizar buscas através de entidades, relacionamentos, manifestações, e no caso da imagem em movimento, variações, que através de agentes computacionais utilizam e devolvem um conjunto estruturado de dados como resposta para diversas perguntas e diferentes contexto. "No entanto, para que isso ocorra, os códigos de catalogação, vocabulários e tesauros deverão ser formatados dentro dos padrões propostos pelo W3C para a Web Semântica" (SOUZA; BEZERRA, 2016, n.p).

A representação do conteúdo de um recurso chama-se representação temática e está relacionada com a classificação e indexação e auxilia na recuperação a partir do conteúdo, já a representação descritiva está relacionada a descrição bibliográfica (TÁLAMO et al., 2011) e suas características específicas. Os termos representam os conceitos e constituem os vocabulários controlados utilizados em indexação (CATARINO; CERVANTES; ANDRADE, 2015, p. 107). O conceito pode ter o seu conteúdo semântico reexpresso pela combinação de outros conceitos, que podem variar de uma língua ou de uma cultura para outra. (ASSOCIAÇÃO BRASILEIRA DE NORMAS TÉCNICAS, 1992, p. 1). A Norma ANSI/NISO Z39.19 define que:

\begin{abstract}
Vocabulário Controlado é usado para melhorar a eficácia dos sistemas de armazenamento e recuperação, sistemas de navegação Web, e outros ambientes que buscam tanto identificar e localizar o conteúdo desejado através de algum tipo de descrição usando a linguagem. O propósito principal de controle de vocabulário é alcançar consistência na descrição dos objetos de conteúdo para facilitar a recuperação. (AMERICAN NATIONAL STANDARDS INSTITUTE; NATIONAL INFORMATION STANDARDS ORGANIZATION, 2005, p. 1, tradução nossa)
\end{abstract}

Segundo CATARINO, CERVANTES e ANDRADE, (2015, p. 107) "no contexto da Web, são vistos esquemas como: tesauros, taxonomias, mapas conceituais, redes semânticas, folksonomias e ontologias". "[...] São sistemas de organização e representação do conhecimento KOS (knowledge Organization Systems) - e servem para fazer a indexação de recursos na Web com diferentes vocabulários (alguns deles controlados, outros não)" (MOREIRO GONZÁLEZ, 2011, p. 16-17 apud CATARINO; CERVANTES; ANDRADE, 2015, p. 107). O desenvolvimento de tesauros para serem 
utilizados em ambientes digitais sofrem reflexos dessa mudança de ambiente, nesse sentido Arano (2005, BOCCATO; RAMALHO; FUJITA, 2008) apresenta quatro itens:

- o enriquecimento da funcionalidade da estrutura dos tesauros a partir da hipertextualidade, possibilitando o estabelecimento de hiperlinks entre os elementos estruturais e as diferentes partes do tesauro.

- a redução dos custos de atualização e manutenção. Devido à crescente informatização dos processos de construção de tesauros e o progressivo abandono do suporte papel para a publicação destas ferramentas, viabilizando uma redução dos custos.

- a integração do usuário nos processos de criação, gestão e otimização dos tesauros, por meio de testes de viabilidade e uso de técnicas ajustadas ao usuário. Isso permite elaborar ferramentas que levem em conta os requerimentos dos usuários, e descartar sua construção como simples estruturas teóricas.

- a possibilidade de aplicar medidas de reutilização e interoperabilidade no momento de planejar e construir os tesauros. Possibilitando assim o aproveitamento e enriqueci enriquecimento da informação conceitual e lingüistica que é gerada para outros recursos.

Dentro desse cenário aumentou o uso do conceito de ontologia dentro dos instrumentos de organização e representação de informações que relacionam novas abordagens computacionais com os instrumentos tradicionais de representação utilizados no âmbito da área de Ciência da Informação demonstrando uma forte tendência de reaproveitamento de tais instrumentos para a elaboração de ontologias de acordo a Catarino e Baptista (2008, p.35):

[...] conforme se observa na descrição do princípio fundamental da WS, um dos componentes fundamentais são os vocabulários controlados, e dentre as diversas camadas da Arquitetura da Web Semântica, é a camada de Ontologias a que suporta a evolução de vocabulários que podem definir relações entre diferentes conceitos. (

Portanto, Catarino, Cervantes e Andrade (2015, p.110) explicam:

Retomando o conceito de vocabulários, de acordo com a W3C Brasil (2012), estes são importantes ferramentas e valiosos instrumentos para organizar os dados de um domínio. Usando OWL (para construir vocabulários, ou 'ontologias') e SKOS (para projetar sistemas de gestão do conhecimento), é possível enriquecer os dados adicionando significados, permitindo que mais pessoas (e mais máquinas) possam reutilizá-los e fazerem mais com os dados.

A eficiência de vocabulários controlados aprimorados para o uso em ambiente digital, Pedraza-Jiménez et al.,(2007 apud BOCCATO; RAMALHO; FUJITA, 2008):

Todavia, como ressalta Pedraza-Jiménez et al. (2007), a Web é um cenário informacional heterogêneo completamente distinto do que se presencia no universo das disciplinas vinculadas no âmbito da documentação. Deste modo, por mais que os tesauros sejam aprimorados a partir das necessidades dos ambientes digitais, torna-se evidente que novos instrumentos tecnológicos concebidos inicialmente em contextos computacionais apresentem contribuições mais significativas para a organização e recuperação de informações em ambientes digitais, destacando-se as ontologias 
Sobre a questão da criação de sistemas de tratamento de informações automatizadas por agentes computacionais, como é o caso do Linked Data, em substituição do trabalho intelectual humano, as máquinas sozinhas não alcançam a qualidade e eficiência esperada, tampouco é desejável que essas linguagens sejam desenvolvidas especificamente para agentes computacionais, mas o contrário, são construídas principalmente para uso de humanos, seguido pelas máquinas, Kobashi et al., 2009, p. 3):

Criar algoritmos potentes para analisar textos, condensá-los e classificá-los ou criar linguagens documentárias por meios automáticos são, ainda hoje, tarefas humanas não transferíveis, na totalidade, para as máquinas. As promessas de automatização total das atividades de tratamento de conteúdos e sua tradução em descritores não foram ainda cumpridas. Serão um dia? Os experimentos realizados atualmente fixam horizontes modestos: parece ser mais factível criar sistemas de auxílio à elaboração de resumos e índices do que criar sistemas efetivamente inteligentes. Com efeito, apesar de inúmeros avanços obtidos, as pesquisas sobre o processamento de textos são, ainda, hipóteses de trabalho em teste, insuficientes para substituir, com qualidade, o trabalho intelectual humano.

\subsection{Representação descritiva no contexto da web semântica}

Quando o Museu Britânico contratou Antônio Panizzi (1797-1879) como bibliotecário assistente aumentaram os debates sobre catálogo e catalogação, pois, o mesmo foi contratado para coordenar os trabalhos de revisão do catálogo da instituição. "Após diversas audiências, Panizzi, em 1839, consegue convencer os membros da comissão de avaliação do Catálogo do Museu a aceitarem as 91 regras que formulara, nascendo assim os primeiros fundamentos da catalogação, dentre os quais se destaca a centralidade do conceito de obra" (SOUZA; BEZERRA, 2016. n.p).

As 91 regras de catalogação declaram as especificidades e funções que um catálogo deve realizar para atingir seus objetivos e fazer que o usuário acesse o documento buscado, conforme segue:

1) [o documento] deve ser considerado e representado no catálogo, não como uma entidade separada, mas como uma edição de determinada obra e de determinado autor;

2) todas as obras de um autor e suas edições devem ser entradas sob um nome definido, usualmente o nome original do autor, independentemente dos diferentes nomes que aparecem nas diferentes obras e edições;

3) todas as edições e traduções de uma obra, independentemente de seus títulos individuais, devem ter entradas sob seu título original, numa ordem prescrita (edições cronologicamente, traduções por língua etc.), de maneira que a pessoa em busca de um livro em particular, encontre-o junto com as outras edições, dando ensejo a uma escolha da edição que melhor sirva a seus objetivos.

4) [as] referências apropriadas devem ser feitas para auxiliar o usuário a encontrar a obra desejada (Fiuza, 1987, p.47 apud SOUZA, BEZERRA, 2016, n.p) 
As idéias de Panizzi foram seguidas por outros catalogadores e os instrumentos foram sendo aprimorados por instituições como a Library of Congress (LC) e a International Federation of Library Associations and Institutions (SOUZA; BEZERRA, 2016).

Durante esse longo tempo as mudanças tecnológicas foram (e ainda são) o ponto de partida para as evoluções sofridas pela representação descritiva ao longo de décadas, através da criação de códigos e protocolos para a catalogação de informação que se moldam aos novos instrumentos, como a passagem da ficha catalográfica a sistemas informatizados, a mudança mais significativa ocorrida nesse novo cenário é a desterritorialização do documento (ALVARENGA, 2003) e uso de metadados. Além disso, a rápida produção de conteúdo e documentos na web, com a expansão de recursos informacionais, trouxe desafios para acomodar instrumentos de representação nos processos de organização e recuperação da informação.

De acordo com Aganette et al. (2017) é no contexto das rápidas mudanças nas tecnologias de comunicação e informação que surge a necessidade de criar estruturas de representação e recuperação modeladas de acordo com novos conceitos, ambientes e recursos; nesse contexto a representação descritiva se conecta a temas atuais como metadados, usabilidade e modelagem de dados. Ainda segundo os autores, a catalogação não é mais pensada como um instrumento isolado dentro dos serviços de recuperação da informação, mas parte do processo comunicativo, seja em ambiente real ou virtual, criando novas demandas e necessidades do século XXI.

Os modos como se deram as primeiras experiências dos usuários com as interfaces da internet através da World Wide Web moldaram as demandas por novas formas de representar e recuperar um recurso, visto que começaram a interligar recursos e navegar por páginas através de hiperlinks. Gracy (2018, p.356, tradução nossa) comenta:

Como os primeiros adeptos da World Wide Web aprenderam rapidamente, a novidade e o poder inicial da Web eram sua funcionalidade de conectar um recurso a outro, seguindo caminhos de informações por meio de hiperlinks que conectavam uma página da Web a outra página da Web. A facilidade de navegar por esse novo cenário e a oportunidade de visualizar listas agregadas de referências a fontes de informações sobre uma entidade, como uma pessoa, lugar, evento ou tópico por meio de mecanismos de pesquisa, alimentou o entusiasmado abraço da World Wide Web. Mas à medida que a web evoluiu, surgiram idéias sobre melhores formas de indexar, buscar e consumir informações. Nas últimas duas décadas, os recursos de pesquisa cada vez mais sofisticados do Google levaram os usuários dos sistemas de informações na Web a ter expectativas cada 
vez maiores para a descoberta de recursos e o uso de todos os tipos desses sistemas.

Outro aspecto significativo das mudanças que afetam usuários e instituições é que o objeto e sua representação não necessariamente estão na forma de catálogos e registros separados do recurso digital. Isso se dá graças aos novos tratamentos da informação que passam a inserir nos objetos a identificação dos elementos que servirão de índice para a recuperação. Alvarenga (2003, p. 36) explica:

Portanto, a representação do conhecimento, em nossos dias, não compreende somente a substituição do documento primário por uma informação catalográfica, considerando-se que o documento a ser tratado não se acha fisicamente em outro espaço, mas no próprio meio que lhe proporciona materialidade e que novas formas de se criar índices e estruturas conceituais para a recuperação encontramse disponíveis.

Nesse novo contexto não existe apenas a representação textual secundária e simbólica, mas as formas de escritas hipertextuais a partir da criação de metadados intrínsecos no próprio documento (ALVARENGA, 2003, p. 33):

No novo contexto de produção, organização e recuperação de objetos digitais, as metas de trabalho não se restringem à criação de representações simbólicas dos documentos constantes de um acervo, mas compreendem a criação de novas formas de escrita para os hipertextos, e a criação dos denominados metadados, muitos dos quais podem ser extraídos diretamente dos próprios objetos, constituindo-se esses em chaves de acesso a serviço dos internautas. Também podem ser criadas descrições dos próprios objetos que eventualmente não tiveram ainda seus conteúdos representados em forma textual primária.

Junto às possibilidades trazidas pelo web surgiram problemas paralelos às rápidas mudanças nas tecnologias, como a falta de padronização, um dos principais motivos que dificultam a recuperação de informação na web focando o problema na modelagem de dados e nas formas de representação da informação (SOUZA; BEZERRA; 2016; AGANETTE et al., 2017). O conceito de documento sofreu alterações que trouxeram perguntas de como organizar, representar e recuperar documentos e recursos digitais e como o usuário e profissionais se relacionam com as máquinas. "A Web atual tem suas informações estruturadas em formatos lineares e textuais, o que dificulta a leitura pelas máquinas" (SOUZA; BEZERRA, 2016, n.p). Dentro desse cenário de novas possibilidades de modelagem de dados e recuperação de informação, Mostafa, Segundo e Sabbag (2016, p. 29) indagam sobre o conceito de documento e a questão da autoria. $\mathrm{Na}$ perspectiva dos teóricos Deleuze, Foucault e Barthes, eles mobilizam diversos conceitos como de rizoma, multiplicidade, agenciamentos e a "morte do autor". Os autores ainda trazem o conceito de tirania do registro apontado por Allison-Cassin, em que a atribuição de autoria pautada pelo uso de metadados torna-se um problema e se perguntam "como 
descrever bibliograficamente este novo documento que é inatribuível sendo que a atribuição de autoria é quase mandatório". (MOSTAFA; SEGUNDO; SABBAG, 2016, p. 30).

Segundo os autores Mostafa e Segundo (2016) as regras para a criação de descrições bibliográficas e os pontos de acesso possuem essa tirania: o AACR (AngloAmerican Cataloguing Rules) e o seu sucessor RDA (Resource Descripton and Access). O RDA tem seu foco no usuário (users tasks) e a tarefa que auxilia o usuário a identificar e utiliza o registro dos atributos e dos relacionamentos na criação de registros de autoridade, desse modo torna-se fundamental que o usuário reconheça a obra e sua ligação de autoria (Assumpção; Santos, 2013 apud Mostafa; Segundo; Sabbag, 2016, p.31). Para Cassin (2012, p. 18 apud Mostafa; Segundo; Sabbag, 2016, p. 31), "a preocupação do modelo conceitual FRBR e da norma RDA em construir com precisão os registros bibliográficos acaba comprometendo a serendipidade que é o encontro ao acaso de outras informações que não as intencionalmente procuradas":

\begin{abstract}
Portanto, considerando a necessidade da inatribuição, por quais caminhos podemos enveredar uma nova práxis epistemológica para a catalogação, classificação e indexação de documentos na era Web? Como criar catálogos que possibilitem a serendipidade por parte dos usuários? Como construir catálogos que permitam o reconhecimento da 'obra como assemblage'? Como pensar a descrição bibliográfica deste novo documento agenciamento? O futuro funcional do controle bibliográfico talvez resida na adoção de um modelo de Linked Data por permitir a ampliação dos espaços para os dados bibliográficos permitindo o rizoma-multiplicidade.
\end{abstract}

Desse modo, antes de discutir quais caminhos, "podemos enveredar uma nova práxis epistemológica para a catalogação, classificação e indexação de documentos na era Web", é sendo necessário rever os atuais instrumentos de representação descritiva e como eles participam das propostas do W3C para a Web Semântica. De acordo com Bermès (2013 apud Serra; Segundo, 2017, p. 167), os catálogos eram ferramentas bibliográficas para a recuperação da informação e gestão da coleção, porém, "o catálogo contém dados e conteúdos e não somente a representação bibliográfica, oferecendo outras possibilidades de localização da informação e utilização de produtos e serviços. "A catalogação, por meio de regras internacionais de representação, orientou a adoção de padrões para favorecer o intercâmbio de registros entre bibliotecas, independentemente do idioma utilizado ou país da agência catalogadora" (Serra; Segundo, 2017, p. 170), fazendo com que uma obra que já tivesse sido catalogada por uma instituição pudesse ter sua descrição compartilhada, principalmente na área da biblioteconomia que disponibiliza itens no catálogo: 
Os padrões para descrição bibliográfica foram fixados em regras como o Anglo American Cataloguing Rules, segunda edição (AACR2) e o International Standard Bibliographic Description (ISBD), porém o intercâmbio dos dados foi favorecido com estipulação dos formatos e protocolos.

Com a mudança para o cenário informatizado, a Library of Congress desenvolveu na década de 1960 o padrão MARC, que foi pensado para facilitar o trabalho de catalogação e não para compartilhamento de registros, que veio ocorrer depois. $\mathrm{O}$ formato MARC foi desenvolvido para transferir a representação descritiva de catálogos em papel para computadores, na passagem de fichas analógicas para digitais, sem explorar as possibilidades dos recursos tecnológicos. "Esta situação não é coerente com o cenário atual" (Serra, Segundo, 2017, p.172).

A partir do novo código, a LC avançou em seu projeto de automação dos catálogos, criando o formato MARC (Machine Readable Cataloging). Ao longo das décadas de 1970 e 1980 o formato evoluiu, mas as discussões sobre os fundamentos da catalogação cessaram (SOUZA, BEZERRA, 2016, n.p). Também ocorreram a disponibilização do Online Public Access Catalogue (OPAC) na Web, e de protocolos como o z39.50 e o Open Archives Initiative - Protocol for Metadata Harvesting (OAI-PMH) que apesar de acordo a Serra, Segundo (2017, p.173):

[...] permitirem o intercâmbio de registros, os catálogos das bibliotecas são ilhas de informação, sem interligação de dados, exigindo a elaboração de pesquisas nos sítios das instituições ou em projetos de bibliotecas digitais, sem compartilhamento de elementos descritivos. A implementação de LD como aplicação prática da web semântica possui elementos que podem alterar esta situação

Segundo Serra e Segundo (2012, p.179) o formato MARC, apesar de há muitos anos ajudar no intercâmbio de registros, mostra-se na atualidade uma ferramenta limitada. Em contrapartida, aplicar a norma RDA, baseada no modelo conceitual FRBR, na descrição de objetos de informação, ajuda no processamento dos dados por máquinas graças ao seu modelo entidade-relacionamento, visto que, justamente pela limitação do MARC em arranjar a criação de relacionamentos entre registros, "a Library of Congress anunciou a iniciativa de um novo padrão de estrutura dos dados, identificado como Bibliographic Framework Transition Initiative (BIBFRAME), lançado em 2011" (COYLE, 2012 apud SERRA, SEGUNDO, 2012, p.179).

"O formato MARC, por ter sido desenvolvido em uma época antes da Web, não é mais capaz de representar toda a quantidade de informações de interesse das bibliotecas 
e facilitar a troca de dados entre instituições e comunidades relacionadas, faz-se necessário sua substituição" (MARCUM, 2011 apud SERRA; SEGUNDO, 2012, p.179).

Por tais motivos e com as mudanças tecnológicas e demandas surgidas nos ambientes digitais, a LC criou a versão MARCXML, com sintaxe em XML, mantendo as características do domínio bibliográfico e com metadados mais flexíveis. "Embora seja amplamente utilizado no ambiente de bibliotecas, o padrão MARC 21 apresenta dificuldades quanto ao seu uso no ambiente Web, principalmente no que se refere à sintaxe necessária para compartilhar seus registros e promover a interoperabilidade dos mesmos, devido a estrutura de seu esquema de metadados" (ARAKAKI et al., 2017, p. 2234).

Ainda de acordo com Aganette et al. (2017, p. 181) em relação ao registro de itens informacionais o AACR2 e o MARC representaram desenvolvimentos significativos quanto à padronização de regras e ao compartilhamento, mas o cenário da rede de internet e das ferramentas da web trouxe o surgimento do FRBR, "que advém de mudanças na natureza dos processos de catalogação, do surgimento de espaços de discussões teóricas e conceituais, que ampliaram as articulações de cunho prático, com o objetivo de suprir as exigências conceituais da descrição bibliográfica". A proposta dos FRBR é "[...] primeiro, fornecer um quadro estruturado, claramente definido, para relacionar dados registrados em registros bibliográficos às necessidades dos usuários destes registros."

"No campo da catalogação descritiva, o primeiro movimento nessa direção foi a criação de um novo modelo conceitual - os Functional Requeriments for Bibliographic Records (FRBR, Requisitos Funcionais para Registros Bibliográficos) criado para estruturar os dados do domínio bibliográfico" (SOUZA; BEZERRA; 2016, n.p).

"O segundo objetivo é recomendar um nível básico de funcionalidade para registros criados por entidades bibliográficas nacionais." (IFLA, 1998, p. 7).

O modelo conceitual FRBR foi proposto por Tillet em 1998. Segundo a autora, o FRBR para catalogação, é a "[...] nova maneira de olhar o universo bibliográfico, um novo vocabulário que esperamos que os designers de sistemas e as futuras gerações de bibliotecários entenderão." (TILLETT, 2007, p. 90, apud ARAKAKI et al, 2017, p. 2235).

Segundo Souza e Bezerra (2016) o FRBR reorganizou os seus elementos através da análise de entidades, atributos e relacionamentos tendo como o objetivo possibilitar uma nova sintaxe uma nova semântica à catalogação, onde cada entidade bibliográfica é 
identificada com atributos únicos, especificando-as antes de integrá-las a partir de relacionamentos no decorrer dos processos de busca e recuperação. "Esse novo paradigma, anunciado pela International Federation of Library Associations and Institutions (IFLA), reatualiza sob novas bases tecnológicas os Princípios da Catalogação". Ainda conforme os autores, os principais teóricos da catalogação Panizzi, Cutter e Lubetzky tinham como principal preocupação ampliar "regras mais intuitivas que se tornassem compatíveis com o conhecimento dos usuários do catálogo" (Ortega, 2011, p. 49 apud Souza; Bezerra, 2016, n.p).

Souza e Bezerra (2016) ao aproximar a catalogação do paradigma da Web Semântica, a IFLA identifica os limites do modelo anterior, que possui um arcabouço teórico-metodológico expresso pelas International Standard Bibliographic Description (ISBD), que se apresentou acanhado em relação às novas tecnologias de organização da informação e do conhecimento que são apoiadas pelo modelo "entidades, atributos e relacionamentos". Segundo Souza e Bezerra ( 2016, n.p):

\begin{abstract}
No entanto, sabe-se que não se pode abrir mão dos padrões, daí a necessidade de adequá-los à dinâmica do mundo digital, cujo sucesso dos canais de comunicação depende do desenvolvimento de linguagens artificiais capazes de fazer a mediação entre os usuários e os conteúdos disponíveis na Web, de modo que essas informações sejam compreensíveis pelos agentes de softwares. É nessa direção que se presencia o avanço do modelo conceitual FRBR: de modelo conceitual do tipo E-R (entidade e relacionamento) para a metodologia orientada ao objeto: o FRBRoo.
\end{abstract}

Na web as informações não são padronizadas e mudam constantemente, o que causa baixa precisão nos processos de recuperação da informação por computadores e agentes computacionais (softwares). Essa inconsistência na estrutura de organização e recuperação na web fez Berners-Lee, o criador da Web, a definir uma proposta para o problema, chamada Web Semântica, para estruturar as páginas da Web (dados e metadados) de modo que homens e máquinas são capazes de recuperar os conteúdos dos sites e bases de dados. (SOUZA; BEZERRA, 2016, n.p). "O novo projeto de estrutura bibliográfica será focado no ambiente da Web, princípios e mecanismos do linked data e no RDF como modelo de dados." (MARCUM, 2011 apud SERRA; SEGUNDO, 2012, p 179).

"Como pensar a descrição bibliográfica deste novo documento agenciamento? 0 futuro funcional do controle bibliográfico talvez resida na adoção de um modelo de linked data por permitir a ampliação dos espaços para os dados bibliográficos permitindo o rizoma-multiplicidade" (MOSTAFA; SEGUNDO; SABBAG, 2016, p. 31). 
Para os autores (MOSTAFA; SEGUNDO; SABBAG, 2016, p. 31) esse novo documento revela um contexto em que o modelo FRBR e o RDA representaria um avanço em relação ao AACR, justamente por ser pensado por um viés de uma metodologia baseada na técnica de análise de entidades.

Bermès (2013 apud SERRA; SEGUNDO, 2012, p. 180) "pontua que o LD pode ser empregado por bibliotecas que possuem datasets relevantes e cujos dados podem ser reutilizados". Em concordância com Serra e Segundo (2012, p. 180) neste contexto, é possível dividir as instituições em dois grupos: o primeiro tipo, são as com acervos importantes e significativos com obras raras, coleções únicas, assim como as instituições que realizam controle de autoridades, tesauros, vocabulários controlados e outros instrumentos. O segundo tipo são as instituições como bibliotecas que podem utilizar da diversidade de datasets como DBpedia ou Geonames, possibilitando através do LD que se publique catálogos com dados conectados a fontes externas na web. "A interoperabilidade é funcionalidade básica nestes dois casos, afinal a biblioteca pode tanto dispor seus dados para serem utilizados na Web, como usufruir de datasets publicados". (SIMIONATO et al., 2018, p. 180).

Esse acercamento do linked data e da Web de Dados com as unidades informacionais aumenta a compreensão das máquinas para conteúdos dos recursos da Web (RASMUSSEN-PENNINGTON 2016 apud SIMIONATO et al. 2018, p. 300).

"O cenário apresentado aponta para um futuro em que as aplicações deverão estar integradas aos principais serviços da Web, obrigando os bibliotecários, os desenvolvedores e as organizações a pensarem na aplicação das tecnologias semânticas para disponibilizar seu conteúdo" (SIMIONATO et al., 2018, p. 301).

Com a evolução da internet desde o surgimento na década de 1960 a internet tem evoluído graças ao trabalho World Wide Web Consortium (W3C) para o desenvolvimento de normas, recomendações e tecnologias que deem suporte à Web Semântica. Um dos objetivos para os próximos estágios da web é embutir inteligência aos dados disponíveis na web.

“[...] Para tanto, é necessário que se padronizem tecnologias, linguagens e metadados descritivos. Dentre as iniciativas do W3C há a proposta de um modelo de descrição de recursos da Web, o Resource Description Framework (RDF) que é fundamental para a Web Semântica". (CATARINO; CERVANTES; SOUZA, 2013, n.p) 
As práticas da $\mathrm{Cl}$ estão relacionadas aos propósitos do W3C,

"[...] já que a base para a Web Semântica é um modelo de descrição no qual são aplicados metadados descritivos, inclusive os bibliográficos e arquivísticos, tais como Dublin Core (DC), Resource Description and Access (RDA) e Enconded Archival Description (EAD)". (CATARINO; CERVANTES; SOUZA, 2013, n.p)

A base da Web Semântica é o RDF que permite que a identificação de recursos por meio de identificadores da Web, denominados Uniform Resource Identifiers (URI) (SOUZA, BEZERRA, 2016, n.p). Além disso, o Resource Description Framework (RDF) estrutura as relações existentes entre os recursos e tem como foco principal a representação dos relacionamentos (RAMALHO, 2016, p. 295). “Em ambas as áreas (descritiva e temática) o modelo RDF aparece como base para a aplicação das práticas da organização da informação conforme segue" (CATARINO; CERVANTES; SOUZA, 2013, n.p).

O RDF é formado por uma estrutura de triplas de associação entre sujeito, objeto e um predicado. Ferreira e Santos (2013, p. 21) complementam tal questão afirmando que:

[...] o modelo RDF oferece a possibilidade para as comunidades de descrição de recursos definirem a semântica de seus metadados de maneira formal, isto é, definindo o significado dos elementos de metadados, conforme as suas necessidades específicas de descrição, em um modelo processável por máquinas.

De acordo a Laufer (2015) no guia da CEWEB:

Resources Description Framework (RDF) é um arcabouço para representar informações na Web. RDF permite fazer afirmações sobre recursos. Recursos são quaisquer coisas, tanto concretas quanto abstratas. Uma determinada empresa, uma pessoa, uma página Web são considerados recursos. Um sentimento, uma cor, também são recursos. (Laufer, 2015, CEWEB)

Segundo Catarino, Cervantes e Souza (2013) os próprios conceitos da web semântica deixam clara "[...] a relação da práxis das unidades de informação na descrição de itens, que se fundamenta nas teorias da ciência da informação, com o que se propõem para a web de dados". Mey (1995, p. 6) afirma que "a riqueza da catalogação repousa nos relacionamentos entre os itens estabelecidos, de forma a criar alternativas de escolha para os usuários". A busca pela construção de relacionamentos entre itens, obras, entidades é a base comum entre a catalogação e a web de dados, por isso, "[...] tanto dos profissionais catalogadores quanto os que propõem a Web Semântica, há a preocupação em dar aos usuários formas mais ricas e amplas de recuperação da informação". (CATARINO; CERVANTES; SOUZA, 2013, n.p) 
Supõe-se que para incluir os tradicionais catálogos no ambiente da Web de Dados, ou seja, transformar os dados bibliográficos em dados lincados na Web, faz-se necessário mudar os dados já existentes que se utilizam de MARC ou DC, por exemplo, em dados modelados em RDF. Deve-se, ainda, tornar o modelo conceitual FRBR e o código de catalogação RDA, recentemente publicado como sucessor do AACR, em base RDF. Além do que, escrever os vocabulários controlados existentes em linguagens propostas pelo W3C tais como RDF Schema, SKOS e OWL.

\subsection{FIAF e a representação descritiva}

A FIAF acompanhou nos últimos anos as mudanças sofridas no universo da descrição de imagens em movimento, auxiliando instituições a atualizarem ou substituir seus antigos Manuais de catalogação para era digital. Segundo Van Malssen (2017, p. 126, tradução nossa)

"A pressão pelo acesso on-line à informação, bem como a necessidade de mais dados compartilháveis, acionáveis e reutilizáveis na era da rede, trouxe um foco na criação de metadados, um termo e conceito que era praticamente desconhecido quando as Regras de Catalogação da FIAF para Film Archives foi publicado em 1991".

O Manual de Catalogação de Imagens em Movimento da FIAF 2016 inclui todo o ciclo de vida do conteúdo (proveniência, preservação, acesso), dessa forma os metadados resultantes atendem às necessidades de todos os tipos de usuários finais, humanos ou de computador.

O Manual da FIAF também considera o contexto da explosão de conteúdos de imagem em movimento em suporte digital ou digitalizados, desse modo ajudando instituições sem orientações atualizadas, que usam manuais de catalogação bibliográficos voltados para o digital e que trabalham

"especificamente imagens em movimento ou padrões de estrutura de metadados (por exemplo, EBUCore, PBCore) que se concentram nos atributos a serem capturados, mas não fornecem orientações detalhadas sobre como criar descrições de conteúdo e recurso" (Van Malssen, 2017, p.126).

Além disso, Van Malssen (2017, p.126) cita:

O Manual da FIAF define quatro possíveis entidades hierárquicas: Trabalho (o conteúdo intelectual expresso como uma imagem em movimento), Variante (mudança para uma Obra que não altera significativamente o conteúdo, por exemplo, adição de legendas), Manifestação (incorporação de uma Obra ou Variante), para um contexto ou formato de publicação específico e Item (uma exploração ou cópia da Manifestação). Para ajudar o catalogador a determinar uma distinção entre essas entidades, o Manual fornece árvores de decisão úteis e 
ilustrativas e vários exemplos. Estas quatro entidades centrais têm relações bem definidas umas com as outras, bem como com entidades adicionais, tais como Agentes (por exemplo, elenco, distribuidores, arquivos, etc.) e Eventos (por exemplo, publicação, produção, preservação).

Segundo as conclusões da autora (Domínguez-Delgado e López-Hernández, 2016, p. 14) apesar do trabalho considerável do FIAF e do CEN durante os últimos anos, é preciso se adequar à nova era digital e tecnológica, ou seja, analisar mais profunda e sistematicamente o conteúdo dos filmes em suas recomendações para os arquivos de filmes, colocar mais atenção no conteúdo, caso contrário correm o risco de que usuários, pesquisadores e cidadãos, em geral percam seu interesse por esse importante patrimônio como recurso de informação e cinema. Van Malssen (2017, p. 127):

O Manual é uma contribuição crucial para o cenário em constante mudança de catalogação de imagens em movimento e uma conquista altamente recomendável. Como próximo passo, espero que a Comissão de Catalogação e Documentação da FIAF considere a publicação das listas de valores no Apêndice $D$ como vocabulários de Linked Data (dados vinculados), ou trabalhe com outros grupos para ampliar um conjunto existente de vocabulários.

\subsection{FIAF Metadados}

De acordo a Domínguez-Delgado, R. e López Hernández (2017, p. 656) em 1991, as Regras de Catalogação da FIAF para Arquivos de Filmes não tinham nenhum campo de conteúdo nas seis primeiras áreas obrigatórias de catalogação. Apenas na área "Notes" opcional, existiam referências ao conteúdo do filme: o campo Natureza, escopo ou forma artística do item (FIAF, 1991, p. 107, tradução nossa) -o gênero de filme relevante -, o campo Conteúdo e o campo Sumário. Em Conteúdos, poderia ser incluída "uma lista de conteúdos de cada segmento que compõe um filme que consiste em diferentes partes, como noticiários" (FIAF, 1991, p. 125, tradução nossa). O resumo feito pelos arquivistas "deve ser uma descrição precisa e objetiva do conteúdo real do filme, baseado na visualização do item" (FIAF, 1991, tradução nossa). Apesar, do resumo não ser obrigatório "destina-se a auxiliar o usuário na pré-seleção de materiais de imagens em movimento para visualização, ajudando-o a eliminar materiais indesejados e a concentrarse nos itens mais úteis para seu uso" (FIAF, 1991, tradução nossa). Além disso, o resumo deveria incluir (FIAF, 1991, p. 126): 
-Introdução delineando o enredo, sujeito ou natureza da imagem em movimento, de preferência incluindo gênero (s), período (s) de tempo e localização (ões) dos eventos representados, se apropriado.

-Se conhecidos, indicam a presença e a natureza de filmagens ou trechos de outros materiais de imagens em movimento que são usados

Porém, passados anos de pesquisa e experimentação o Manual de Catalogação de Imagens em Movimento da FIAF 2016, revela que "o campo da imagem móvel em arquivo mudou dramaticamente nos últimos anos, com avanços tecnológicos revolucionando práticas de catalogação, preservação e acesso" (2016, p. 1). Embora os campos de descrição de conteúdo dessas regras não estejam mais em Notas opcionais, mas em dois espaços específicos - Descriptografia e Assunto / Gênero / Formulário -, é recomendado apenas estas indicações no primeiro deles (Domínguez-Delgado, Hernández, 2017, p. 656). A FIAF (2016, p. 126) publicou que:

Escreva um resumo conciso, objetivo e não crítico do conteúdo da imagem em movimento Trabalho e / ou Variante. As descrições de conteúdo podem ser sinopses, uma breve descrição de uma sentença, listas de tomadas, etc. Pode haver mais de um tipo de descrição de conteúdo no registro (...) Se resumos aceitáveis já estiverem disponíveis em fontes secundárias, os catalogadores podem usá-los, em vez de tomar o tempo para preparar resumos próprios (...) Uma descrição de conteúdo também pode ser uma lista de filmagem ou uma listagem do conteúdo de um Trabalho / Variante agregado.

Além disso, “a descrição do conteúdo pode ser baseada em uma visão da Obranão necessariamente, como recomendado em 1980 e como os teóricos aconselham -, acompanhando documentação ou fontes secundárias, mas a fonte deve ser claramente notada".

Apenas para trabalhos não editados e "Onde o tempo e os recursos permitirem, cada cena deve ser resumida" segundo Domínguez-Delgado e López Hernández (2017, p.656). No entanto, é, pelo menos, apontado que "se houver planos de particular importância ou interesse - por exemplo, pessoas ou lugares proeminentes - estes devem ser gravados. Caso contrário, uma descrição geral de cenas e sequências basta"(FIAF, 2016, p. 127). Por outro lado, no campo Assunto / Gênero / Forma, recomenda-se (FIAF, 2016, p. 44):

Fornecer acesso a Obra por meio de assuntos (ou identificadores de assunto) que descrevam o conteúdo da Obra (ou seja, sobre o que é a Obra) - entretanto lugares, tempos ou nomes de pessoas ou entidades não são considerados como registrados, como recomendado por teóricos no campo da biblioteconomia de imagens em movimento (Caldera Serrano e Sánchez Jiménez, 2009) -. Use um padrão de valor de dados existente, como cabeçalhos de assunto da Biblioteca do Congresso (LCSH). Alternativamente, ou adicionalmente, use padrões como Classificação Decimal Universal (UDC), Classificação Decimal de Dewey (DDC) o único recomendado nas anteriores regras da FIAF de 1991 -, ou equivalente (...) 
Além disso, o acesso a Obra pode ser fornecida por meio de gênero (s) e / ou forma (s) (ou identificadores) dos quais a Obra é um exemplo.

Sobre os padrões de metadados para obras cinematográficas (CWS) publicados pelo CEN, o primeiro deles, EN 15744 (2009), era focado no conteúdo cinematográfico no campo Gênero (Flores Riesco, 2009, p. 31 apud Domínguez-Delgado, Hernández, 2017, p. 656), recomendando o uso de descritores extraídos de um vocabulário controlado, entretanto, esse padrão não considera nem o resumo geral nem qualquer tipo de indexação. (Domínguez-Delgado, Hernández, 2017, p. 656, tradução nossa). Diferentemente, a norma EN 15907 (2010) possui quatro referências relacionadas à análise de conteúdo do filme. Nos Elementos espaciais, é possível encontrar dois campos de conteúdo: descrição do conteúdo e campos de assunto, que pode ser definido como "termos controlados e não controlados podem ser usados juntos, mas não dentro de um único conjunto de termos de assunto" (CEN, 2010).

Segundo as autoras Domínguez-Delgado e Hernández (2017, p. 657) ocorreu uma evolução e uma maior preocupação com a descrição de conteúdo dos filmes nos padrões mais recentes do CEN em comparação a 2009 e no último manual de catalogação da FIAF devido ao fato de ser possível inserir na descrição do conteúdo do filme, lugares e horários, entretanto, não são exploradas informações sobre esses campos. "Devido a essas deficiências nos metadados de filmes e padrões de catalogação, alguns arquivos de filmes criaram algumas iniciativas para melhorar as possibilidades de acesso às coleções de filmes de seus usuários, como o projeto I-Media-Cities (IMediaCities.eu, 2016-2019)" (FIAF, 2016, p. 44). 


\section{Web semântica e informação}

\subsection{Web semântica}

Os catálogos web de sistemas de bibliotecas, arquivos e museus são recursos informacionais fechados com tecnologias, padrões e interfaces próprias que não permitem a navegação dos usuários entre os recursos internos e externos dos sistemas e a solução para esse problema é a publicação direta de links semânticos e URIs na Web (MARCONDES, 2012). Segundo o autor, a internet atualmente é formada por links convencionais, que não passam de etiquetas para compreensão humana, são "meios para que programas navegadores, a partir de um recurso, acessem outro, sem explicitar qual o significado da ligação entre os recursos” (MARCONDES, 2012, p. 173); o autor cita que os links semânticos possibilitam uma navegação natural e intuitiva dos usuários pela interface e orientada por links, diretamente de recurso para recurso sem a necessidade de uma interface específica de consulta.

Na web 2.0 é possível navegar entre páginas clicando em links inseridos através de etiquetas em documentos $(\mathrm{HTML})$ que redirecionam o usuário para o endereço URL colocado naquela linha de código. Esse percurso hipertextual é formado por links convencionais, visto que as relações entre os recursos podem estar claras para o usuário como, por exemplo, os contextos social e cultural, mas essas conexões não são entendidas pelo computador, ou seja, a máquina não consegue coletar e extrair dados para tirar conclusões, o que é denominado inferência. Os links semânticos são justamente recursos para publicar dados na internet seguindo alguns padrões e tecnologias para que o computador possa consultar esses dados e levantar inferências usando as descrições publicadas dataset do linked data. Desse modo, a experiência do usuário durante a navegação entre catálogos de instituições não é apenas hipertextual entre páginas, mas também entre recursos informacionais, pois, no contexto da web semântica, os links são para recursos e não apenas links para outras páginas.

Segundo as informações disponíveis no próprio website o "Consórcio World Wide Web (W3C) é uma comunidade internacional que desenvolve padrões com o objetivo de garantir o crescimento da web. Missão do W3C: conduzir a Web ao seu potencial máximo.". O linked data é uma das iniciativas de W3C para desenvolver a internet e garantir seu crescimento. Ainda segundo as informações do website da W3C: 
A Web Semântica é uma Web de Dados-de datas e títulos e números de peças e propriedades químicas e qualquer outro dado que se possa conceber. A coleção de tecnologias da Web Semântica (RDF, OWL, SKOS, SPARQL, etc.) fornece um ambiente onde o aplicativo pode consultar esses dados, extrair inferências usando vocabulários, etc. (tradução nossa)

Para produzir links semânticos, são utilizados padrões da Web Semântica, RDF e URI: "The glue that holds together the traditional document Web is the hypertext links between HTML pages. The glue of the data web is RDF links" (BIZER et al., 2007 apud MARCONDES, 2012). Segundo Marcondes (2012), os links semânticos exploram e enriquecem cognitivamente o significado das ligações entre os recursos.

Sistemas informatizados de instituições usam base de dados para descrever os recursos informacionais. Muitos desses arquivos são caracterizados pela multimodalidade, o que dificulta o tratamento e segundo Silva (2014, p. 19):

\begin{abstract}
Um problema comumente verificado nas instituições que fazem uso de tais sistemas está no tratamento integrado das bases de dados, geralmente heterogêneas e em formatos multimídia, e na ausência de padronização nos formatos de descrição. A descrição de inúmeros itens geralmente é realizada de maneira independente, com padrões idiossincráticos de descrição, ressaltando diferentes características a serem descritas e diferentes terminologias para descrevê-las.
\end{abstract}

Segundo as informações disponíveis no próprio website o "Consórcio World Wide Web (W3C) é uma comunidade internacional que desenvolve padrões com o objetivo de garantir o crescimento da web. Missão do W3C: conduzir a Web ao seu potencial máximo.". O Linked Data é uma das iniciativas de W3C para desenvolver a internet e garantir seu crescimento. Ainda segundo as informações do website da W3C:

A Web Semântica é uma Web de Dados-de datas e títulos e números de peças e propriedades químicas e qualquer outro dado que se possa conceber. A coleção de tecnologias da Web Semântica (RDF, OWL, SKOS, SPARQL, etc.) fornece um ambiente onde o aplicativo pode consultar esses dados, extrair inferências usando vocabulários, etc. (tradução nossa)

Para alcançar a chamada web semântica (web de dados ou web 3.0), Berners-Lee (2006) postulou quatro princípios para o paradigma Linked Data, propondo que todos os dados publicados na Web tornarse-iam parte de um espaço único de dados globais, a saber: i) use URIs para dar nomes as coisas; ii) use HTTP URIs para que pessoas possam identificar esses nomes; iii) quando alguém identificar um URI, forneça informação útil usando padrões da Web Semântica, tais como RDF e SPARQL; e iv) inclua links para outras URIs, de modo a possibilitar a descoberta de mais coisas.

A arquitetura da web semântica segundo as definições da W3C possui níveis de interação; um dos níveis é a camada da ontologia, onde são definidos padrões para 
descrever ontologias e nas camadas anteriores propostas pelo W3C (URI, Unicode, XML, Namespaces, RDF, RDFS e OWL) são definidos os padrões de descrição para acrescentar semântica às informações dos recursos de forma que possam ser interpretadas pelos sistemas informatizados. Nesse sentido os modelos conceituais surgem como alternativas para evitar problemas de comunicação entre usuário e máquinas, sendo que a modelagem conceitual pela perspectiva ontológica definida por Silva (2014, p. 52) como importante no processo de desenvolvimento de ontologias pelas seguintes razões: Tal fase possibilita organizar de forma coerente os elementos ontológicos de um domínio. É na fase de modelagem que se torna possível determinar um conjunto de conceitos com compromissos ontológicos estabelecidos para a construção da conceituação para o domínio de interesse, que, nesta tese, é o domínio multimídia, dessa forma, a ceweb (2015, p.48) afirma que:

Ontology Web Language (OWL) é uma linguagem que estende RDF e RDFS e oferece um conjunto muito mais amplo de tipos de restrições ao conjunto de triplas definidas. Além disso, são oferecidos diversos construtores que permitem, entre outros, a construção de classes complexas a partir de outras definições de classes, e encadeamento de propriedades.

Segundo Gilliland (2008 apud Serra, Segundo, 2017, p.17), os metadados no contexto da web semântica e do linked data são compostos por quatro componentes: conteúdo de dados, estrutura, semântica e formato de intercâmbio. Ainda de acordo Serra, Segundo (2017, p.17) a tabela a seguir mostra a descrição dos quatro componentes, suas respectivas atividades e formas de representação: 
Tabela 1: componentes da web semântica e do linked data: conteúdo de dados, estrutura, semântica e formato de intercâmbio.

\begin{tabular}{|c|c|c|}
\hline Etapa & Atividade & Representação \\
\hline $\begin{array}{l}\text { Conteúdo de } \\
\text { dados }\end{array}$ & $\begin{array}{l}\text { Descrito por meio de regras } \\
\text { orientando o formato e a sintaxe dos } \\
\text { metadados que preencherão os } \\
\text { elementos descritivos. }\end{array}$ & $\begin{array}{c}\text { AACR2, ISBD e Resource } \\
\text { Description and Access (RDA, } \\
\text { Recurso, Descrição e Acesso, } \\
\text { tradução nossa) }\end{array}$ \\
\hline Estrutura & $\begin{array}{c}\text { Composta pelos esquemas de } \\
\text { representação com suas regras, } \\
\text { indicando ordem dos elementos, } \\
\text { campos obrigatórios, campos } \\
\text { repetitivos, hierarquia. }\end{array}$ & $\begin{array}{l}\text { Os campos do MARC, Dublin core, } \\
\text { Encoded Archival Description } \\
\text { (EAD), Web Ontology Language } \\
\text { (OWL), Simple Knowledge } \\
\text { Organization System (SKOS). }\end{array}$ \\
\hline Semântica & $\begin{array}{l}\text { Identificada pelos instrumentos que } \\
\text { são utilizados para preencher com } \\
\text { nomes e termos os elementos de } \\
\text { conteúdo. }\end{array}$ & $\begin{array}{l}\text { São representados pelos } \\
\text { vocabulários controlados, tesauros, } \\
\text { ontologias, autoridades etc., que } \\
\text { usualmente são utilizados para } \\
\text { preenchimento de campos (tags) } \\
\text { que acolhem dados sobre a } \\
\text { temática do recurso bibliográfico. }\end{array}$ \\
\hline $\begin{array}{l}\text { Formato de } \\
\text { intercâmbio }\end{array}$ & $\begin{array}{l}\text { Caracterizado pela sintaxe, com } \\
\text { padrões de metadados legíveis por } \\
\text { máquinas, muitas vezes sendo um } \\
\text { padrão da estrutura de dados. }\end{array}$ & $\begin{array}{l}\text { Neste conjunto estão o MARC XML, } \\
\text { Metadata Encoding \& Transmission } \\
\text { Standard (METS), Metadata Objetc } \\
\text { Description Schema (MODS), } \\
\text { Dublin core XML Schema, } \\
\text { JavaScript Object Notation (JSON). }\end{array}$ \\
\hline
\end{tabular}

Fonte: Segundo Gilliland (2008) apud Serra, Segundo (2017, p.17).

Arakaki destaca que os princípios são "[...] melhores práticas para estruturar e ligar dados. Esse processo facilita a busca de agentes humanos e não humanos e os direcionam em diferentes bases a partir desses dados ligados." (ARAKAKI, 2016, p. 27). (SIMIONATO et al., 2018, p. 302).

Os princípios do linked data oferecem a "[...] possibilidade de otimizar a recuperação e navegação dos dados de acordo com as necessidades informacionais de seus usuários." (SIMIONATO; ARAKAKI; SANTOS, 2017, p. 458). Sobre isso Simionato et al. (2018, p.305) elucidam:

A questão levantada vai ao encontro da proposta da Web Semântica de BernersLee, Hendler e Lassila (2001), quando os autores indicam que os agentes computacionais poderiam auxiliar os usuários a realizarem cruzamentos e relações entre as informações, sem a necessidade de o usuário navegar por diversas páginas fazendo a coleta de cada um dos dados. As consultas construídas permitem que os dados sejam coletados em um único ambiente, sem que um usuário navegue por inúmeras plataformas coletando e cruzando cada uma das informações. 


\subsection{Web semântica e informação audiovisual}

A FIAF usa o termo imagem em movimento, pois o conceito abrange imagens em movimento com e sem áudio, aumentando o espectro de acervos e instituições que podem utilizar os padrões, pesquisas e trabalho colaborativo da instituição. O tempo de reprodução de imagens por segundo que cada suporte possui é responsável pelo efeito de movimento, entretanto, o tempo é uma característica de muitas mídias, não apenas do audiovisual. Já a percepção do movimento é obrigatória em filmes e vídeos. Segundo Gracy (2018):

Mídias baseadas no tempo, como imagens em movimento, gravações de som, animações e obras de arte contemporâneas que incorporam vídeo, filme, slide, áudio ou tecnologias de computador, oferecem um desafio descritivo significativo para administradores de patrimônios, dada a grande variedade de gêneros, formatos e ambientes em que são criados, gerenciados e usados.

Segundo (VAN MALSSEN, 2016) essa delimitação de mídias baseadas no tempo permite aumentar o escopo de instituições e acervos, pois, são fontes de informação de arquivos, documentos históricos, obras artísticas ou ativos comerciais para empresas de entretenimento e organizações de notícias. Um modelo de dados projetados para mídia baseada em tempo precisam fornecer acesso à descrições para recuperação, amparar um grande espectro de requisitos funcionais, garantir a interoperabilidade entre sistemas diferentes. Além disso, esses sistemas precisam interagir perfeitamente com outros sistemas para obter informações de várias fontes e apresentá-las aos usuários de maneira unificada (GRACY, 2018), é preciso atender as especificidades de materiais baseados em tempo, que suportem descrição centrada no objeto e centrada no evento (Van Malssen, 2014).

\section{A iniciativa da Biblioteca do Congresso dos E.U.A, o Marco Bibliográfico}

(BIBFRAME) foi visto como uma oportunidade para se identificar e discutir os requisitos de catalogação que não estão de acordo as lacunas de catalogação de materiais baseados em tempo entre eles a imagem em movimento e os recursos audiovisuais:

O desenvolvimento de um padrão de codificação e expressão de substituição para o MARC oferece uma oportunidade única para identificar e suportar os requisitos de catalogação de imagens em movimento e de sons gravados, bem como outros tipos de conteúdo que não se enquadram no modelo de livro publicado desde o início. Um modelo que utiliza adicionalmente a arquitetura da Web, possibilitando novas oportunidades de pesquisa e descoberta, também é necessário, para que a descrição de recursos possa se tornar mais modular, portátil e interoperável com outros padrões e conjuntos de dados disponíveis para tipos de conteúdo específicos nas comunidades. Estes são os objetivos da Iniciativa do Marco Bibliográfico (BIBFRAME). 
A Biblioteca do Congresso encomendou um estudo com conclusões apresentadas em forma de relatório para avaliar o estado existente de metadados técnicos, estruturais e de preservação de recursos audiovisuais no ambiente bibliográfico na perspectiva dos padrões existentes para metadados audiovisuais, e para fazer recomendações sobre como o BIBFRAME pode suportar a expressão de tais informações. O escopo do estudo evidenciou a função da descrição bibliográfica como uma ferramenta que abrange pesquisa, descoberta e curadoria e gerenciamento de coleções, mas também como ela se enquadra no contexto das propriedades Resource Description Function:

\begin{abstract}
Um dos objetivos principais do estudo foi garantir que os dados existentes encontrados nos registros MARC possam ser migrados para propriedades RDF, definidas pelo BIBFRAME ou outro namespace externo recomendado, o BIBFRAME deve ter uma abordagem documentada para tratar cada campo e subcampo MARC, que inclui aqueles que podem ter mais de uma curadoria do que uma função de acesso. Considerando esses fatores, uma questão-chave torna-se: quão granular deve ser o BIBFRAME em seu apoio a todo o espectro de requisitos de gerenciamento de dados bibliográficos para recursos audiovisuais? Quando outros namespaces, que são mais explicitamente projetados para o gerenciamento de coleções, devem ser usados? Quais são as linhas divisórias entre elas?.
\end{abstract}

De acordo com Van Malssen pelo fato do MARC 21 ser muito usado e ser atual padrão de codificação bibliográfica ele é objeto de estudo para avaliação de campos existentes, foram avaliados os campos existentes dentro do MARC que suportam a expressão / codificação de metadados técnicos para recursos audiovisuais.

Segundo Gracy (2018, p. 355) inúmeras informações valiosas sobre criadores, locais, eventos, tópicos, características de objetos e ações institucionais não são suficientemente representados ou as conexões possíveis de serem feitas ficam presas nos registros dos objetos e que muitas vezes essas informações são encontradas apenas por descoberta acidental. Segundo o autor falta semântica ao conjunto de campos, ocasionaria a falta de acesso à informações escondidas em registros descritivos e o linked data seria uma possibilidade de conectar informações relevantes sobre essas mesmas entidades em outros conjuntos de dados e fontes de informação.

Para colocar em prática os conceitos da web semântica existe o projeto linked data. O conjunto de dados que formam a base de dados são chamados datasets e obedecem às tecnologias e conceitos da web semântica e forma o Linking Open Data Cloud ou Diagrama de Nuvens. Os formatos abertos são descritos a partir de triplas RDF incorporadas e identificadores/endereços persistentes - URI, segundo Grisoto (2016, p. 71): 
Eles passaram a ser divididos em nove categorias e todos com declarações em RDF, a saber: Publicações; Ciências da vida; Cross-domain; Dados Geográficos; Dados Governamentais; Mídia; Dados de Uso Geral; Dados de Redes Sociais e Linguística, os dois últimos adicionados na última atualização de 2014.

Segundo Silva (2014, p. 120) o "projeto consiste em identificar conjuntos de dados (data sets) disponíveis sob licença aberta, convertê-los para triplas em RDF, de acordo com os princípios Linked Data, mencionados anteriormente, e finalmente publicá-los na Web de dados, formando uma nuvem de dados interligados." Os datasets onde se encontram os recursos audiovisuais são chamados de Mídias e agrupam distintos tipos e formatos de recursos informacionais, como sonoros e multimídia. Grisoto (2016) conclui que os datasets (conjuntos de dados) sobre os recursos audiovisuais presentes no Linking Open Data Cloud estão na categoria mídia e possuem 21 datasets, entretanto, a autora percebeu que "o conjunto de dados investigados refere-se em sua maioria à informação sobre música e não necessariamente a recurso audiovisual, que é considerado neste trabalho como recurso que contenha imagem e som".

A Linked Movie Data Base (LMDB) é uma base de dados da nuvem LOD para os recursos audiovisuais que merece destaque pelo fato de ser específica para filmes, com informações sobre os filmes, atores, diretores, personagens, trilhas sonoras, compositores, entre outras; a base de dados contém informações estruturadas em RDF, possibilitando a construção de aplicações que façam inferências sobre esses dados, conectando e relacionando recursos. Além dela, os autores destacam a base de dados DBpedia que, diferentemente da LMDB, contém outras informações não somente audiovisuais, "sendo uma base de domínio geral, com dados de autoridade, filmes, locais, datas, programas de televisão, entre diversas outras temáticas." (SIMIONATO et al., 2018, p. 299).

Dentre as características das instituições culturais, no âmbito dos recursos audiovisuais, Simionato et al., (2018, p. 302) destacam a:

1) custosa tarefa dos usuários de reunir e relacionar dados deste domínio no âmbito da Web tradicional e, com

2) grande dificuldade, localizar determinadas informações e compilar os dados necessários para uma compreensão clara do cenário que se deseja investigar.

Para explorar a abundância de informações audiovisuais no Linking Open Data os autores Simionato et al. (2018, p. 305) analisaram o dataset LMDB: "Um exemplo da granularidade e do tipo de dados que são apresentados nessa base de dados pode ser visto quando se busca consultar e quantificar os gêneros dos filmes que um determinado 
ator fez em sua carreira", para isso os autores realizaram uma consulta para a contagem dos gêneros dos filmes que o ator lan McKellen participou. Entretanto Simionato et al. (2018) não abordam a perspectiva da representação descritiva de informação audiovisual. O foco da pesquisa é o nível de relações que podem ser extraídas do dataset de forma automatizada para os pesquisadores e interessados nesta área e os resultados podem ser observados no capítulo dedicado ao referencial teórico: o intuito da pesquisa desses autores não é o mapeamento de normas de descrição bibliográfica ou da área do audiovisual para tecnologias da web semântica, entretanto, fazem parte do referencial teórico por demonstrarem de forma clara e objetiva como é possível extrair informações e criar relações usando os datasets audiovisuais. Nesse caso as relações são feitas para agrupar informações, por exemplo: a entidade presente no dataset, no caso o ator lan McKellen, pode ser considerada como atributo de uma obra num modelo conceitual, como FRBR e como um campo de item nas normas/termos descritivos, desse modo uma busca pela entidade (rdf) e/ou atributo (frbr) e/ou campo (MARC) lan McKellen é possível ser agrupada pelo seu gênero cinematográfico. "Outro exemplo que expande as formas tradicionais de buscas e de recuperação da informação seria a realização de consultas dentro de um universo de personagens criados por um estúdio"( SIMIONATO et al., 2018, p. 306).

\subsection{Audiovisual e Linked Data}

A web semântica se apresenta como a possibilidade de compartilhar e integrar recursos sem a presença de programas mediadores e gerenciadores, não utilizando um banco de dados para centralizar e sem a padronização dos catálogos como pode ser visto no projeto Europeana. Segundo Grisoto (2016, p. 73):

O uso de URI's como identificadores universais permite que os hiperlinks sejam definidos entre entidades diversas, desse modo o Linked Data permite a concentração em um mesmo local desses dados ligados por meio dos hiperlinks e que estes se conectem outras diversas fontes de dados. Os formatos proprietários por sua vez, permanecem isolados sem possibilidade de realizar tal conexão.

Grisoto (2016) conclui que houve dificuldade para encontrar exemplos de descrição de recursos sobre informação audiovisual em RDF/XML nos datasets de mídias. A autora obteve êxito ao identificar o uso das tecnologias da Web Semântica nos conjuntos de dados, mas há muitas lacunas na publicação para a publicação em formato aberto sobre recurso audiovisual: "houve dificuldade de encontrar exemplos de descrição de recursos sobre informação audiovisual em RDF/XML", e exemplos significativos de estruturação 
desse tipo de informação em formato aberto, "não contemplando, portanto as melhores práticas propostas pelo Linked Data, uma vez que a maior parte dos conjuntos de dados estão sob licença Creative Commons e deveriam possibilitar acesso a informações contidas nos conjuntos de dados" (GRISOTO, 2016).

Segundo Grisoto (2016, p. 74) "[...] a seleção dos conjuntos de dados que possuíam alguma menção a material audiovisual" estão os projetos listados abaixo:

1. Open Images: Material de arquivo audiovisual europeu.

2. EU CONSILIUM - Public votes6: Disponibiliza as Sessões do Conselho Europeu por meio de material audiovisual.

3. datos.bne.es: Contém dados retirados do catálogo bibliográfico e de autoridade da Biblioteca Nacional Espanhola, contendo recursos eletrônicos, manuscritos, periódicos, mapas, gravuras, fotografias, música impressa, gravações de som e audiovisuais.

4. DBTropes.org: Contém descrições de vários filmes, livros e outros itens, e associa estes com tropos (dispositivos de escrita e convenções).

5. Last. FM RDFization of Events, Artists, and Users: Sem descrição.

6. BBC Programmes: Programa de TV e rádio transmitido pela BBC.

7. Prelinger Archives: Os Arquivos Prelinger é uma coleção de filmes relacionados com a história cultural dos EUA, a evolução da paisagem americana, a vida cotidiana e história social. Foi fisicamente localizado em Nova York, de 1982-2002 e está agora em San Francisco.

8. IPTC News Codes: O IPTC não só fornece formatos de troca de notícias para a indústria de notícias, mas também cria e mantém conjuntos de conceitos a serem atribuídos como valores de metadados para objetos de notícias como textos, fotografias, gráficos, arquivos de áudio e vídeo e córregos.

9. EU Parliament Media Library: Este conjunto de dados contém informações sobre conteúdo multi-media publicado pelo Parlamento Europeu em http://audiovisual.europarl.europa.eu/.

10. Europeana Linked Open Data: Todos os conjuntos de dados Europeana podem ser explorados, acessados e baixados através do endpoint SPARQL disponível em http://europeana.ontotext.com/. Os dados são representados no modelo de dados Europeana (EDM).

11. BBC Wild life Finder: Informações sobre animais, espécies, habitats, contém fotos, vídeos, histórias, etc.

12. Linked Movie DataBase: Informações relacionadas sobre filmes.

13. Open Media Database: OMBD (banco de dados de mídia aberta) é um banco de dados livre para mídia filme. Não há como definir a equipe editorial, mas sim um grande número de viciados em cinema e amantes que oferecem seu tempo para fornecer o material e desenvolver o site.

14. Event Media: Este conjunto de dados é composto de eventos e descrições de mídia associados a estes eventos. É obtido a partir de três grandes diretórios de eventos públicos (last.fm, agitados e futuras) representados com a ontologia LODE e de grandes diretórios de mídia (Flickr, Youtube) representados com o W3C mídia Ontologia. 
A Linked Movie Data Base (LMDB) é específica para filmes, com informações sobre os filmes, atores, diretores, personagens, trilhas sonoras, compositores, entre outras; a base de dados contém informações estruturadas em RDF, possibilitando a construção de aplicações que façam inferências sobre esses dados, conectando e relacionando recursos. A base de dados DBpedia, diferentemente da LMDB, contém outras informações não somente audiovisuais, mas de domínio geral, com dados de autoridade, filmes, locais, datas, programas de televisão, entre outras temáticas.

A partir de consultas realizadas com o SPARQL dentro do conjunto de dados da LMDB e da DBpedia (SIMIONATO et al., 2018, p. 307) demonstram como "consultas realizadas na LMDB exploram alguns dos principais relacionamentos que podem ser realizados dentro desse conjunto de dados". Segundo os autores as consultas podem englobar a localização dos produtores, os escritores e os diretores de um filme, assim como recuperar os filmes de uma determinada série, os locais de gravação e o país que produziu um filme, já a DBpedia pelo fato de apresentar dados de domínio geral é possível explorar outros tipos de informações relacionadas aos filmes, "além disso, a DBpedia contém um grande número de classes e de entidades que permitem recuperar os dados, explorando uma quantidade maior de relações". Ainda Simionato et al., 2018, p. 308):

Vale destacar que os níveis de conexões existentes são inúmeros, havendo possibilidades de aprofundar consideravelmente as ligações realizadas, com a finalidade de tornar explícito um conjunto grande de relações. Ressalta-se que a complexidade do âmbito audiovisual demonstra, claramente, como o SPARQL e o RDF podem trazer contribuições para este cenário, em que diversas particularidades podem se relacionar. 
Tabela 2: Tabela 2: Metadados e Vocabulários relevantes para o contexto multimídia.

\begin{tabular}{|l|l|}
\hline Vocabulário & Característica \\
\hline Dublin Core & $\begin{array}{l}\text { Fornece classes e propriedades genéricas para descrever artefatos } \\
\text { criados pelo homem, principalmente no domínio bibliográfico. O } \\
\text { vocabulário consiste em descrever principalmente proveniência, formato, } \\
\text { idioma, direitos autorais e itens físicos. Cf. http://purl.org/dc }\end{array}$ \\
\hline $\begin{array}{l}\text { Friend of a } \\
\text { Friend }\end{array}$ & $\begin{array}{l}\text { Descreve pessoas, organizações e relacionamentos entre eles na intenção } \\
\text { de modelar uma rede social global. Cf. http://xmlns.com/foaf/0.1 }\end{array}$ \\
\hline $\begin{array}{l}\text { Basic Geo } \\
\text { Vocabulary }\end{array}$ & $\begin{array}{l}\text { Define propriedades para a representação de coordenadas geográficas } \\
\text { (latitude, longitude e altitude). Cf. } \\
\text { http://www.w3.org/2003/01/geo/wgs84_pos\# }\end{array}$ \\
\hline $\begin{array}{l}\text { Creative } \\
\text { Commons }\end{array}$ & $\begin{array}{l}\text { Fornece termos e classes para representar informação legal sobre obras, } \\
\text { licenças associadas e permissão de distribuição e uso. Cf. } \\
\text { http://creativecommons.org/ns\# }\end{array}$ \\
\hline $\begin{array}{l}\text { Review } \\
\text { Vocabulary }\end{array}$ & $\begin{array}{l}\text { Fornece termos que representam revisões, críticas e comentários para } \\
\text { objetos arbitrários. Cf. http://purl.org/stuff/rev\# }\end{array}$ \\
\hline $\begin{array}{l}\text { Multimedia } \\
\text { Oetadata } \\
\text { Ontology } \\
\text { (M3O) }\end{array}$ & $\begin{array}{l}\text { Fornece um framework para a integração de aspectos centrais de } \\
\text { metadados multimídia. Cf. http://m3o.semantic-multimedia.org/ }\end{array}$ \\
\hline $\begin{array}{l}\text { Core Ontology } \\
\text { for Multimedia } \\
\text { (COMM) }\end{array}$ & $\begin{array}{l}\text { Fornece primitivas para explicitar a composição de um objeto mídia e o } \\
\text { que nele deve ser representado. É considerada uma ontologia bem } \\
\text { fundamentada para anotação multimídia. Cf. } \\
\text { http://www.unikoblenz.de/FB4/Institutes//FI/AGStaab/Research/comm/ } \\
\text { Ontology/ }\end{array}$ \\
\hline $\begin{array}{l}\text { WusC Exif } \\
\text { Vocabulary }\end{array}$ & $\begin{array}{l}\text { Especifica formatos a serem usados para imagens e sons em câmaras } \\
\text { digitais. Cf. http://www.w3.org/2003/12/exif/ }\end{array}$ \\
\hline $\begin{array}{l}\text { Define termos para uma diversidade de informação relacionada à música, } \\
\text { variando de representação de obras musicais. Cf. http://purl.org/ontology/ } \\
\text { mo/ }\end{array}$ \\
\hline
\end{tabular}

Fonte: Silva (2014, p.35).

As duas principais tecnologia da web semântica são o RDF e o SPARQL, a primeira está relacionada a representação e descrição dos metadados e a segunda é a ferramenta de busca para informações estruturadas em triplas RDF. De acordo a Santarém Segundo (2014, p. 3870): "[...] o SPARQL é um conjunto de especificações que fornecem linguagens e protocolos para consultar e manipular o conteúdo publicado em RDF na Web.".

De acordo a Simionato et al. (2018, p.305) uma consulta com a contagem dos gêneros dos filmes que o ator lan McKellen participou, com dados estruturados em RDF e utilizando uma interface de busca SPARQL teria como resultado obtido a figura 1: 
Figura 1: Contagem do gênero dos filmes estrelados por um ator.

\begin{tabular}{|c|c|c|}
\hline \multirow{7}{*}{$\begin{array}{l}\text { SELECT ?nome_genero (count (*) as ?contagem) } \\
\text { WHERE } \\
\text { \{ } \\
\text { ?ator movie:actor_name "Ian McKellen". } \\
\text { ?filmes movie:actor ?ator; } \\
\quad \text { movie:genre ?genero; } \\
\quad \text { rdfs:label ?nome_filme. } \\
\text { ?genero movie:film_genre_name ?nome_genero } \\
\text { \} } \\
\text { GROUP BY (?nome_genero) } \\
\text { ORDER BY DESC (?contagem) }\end{array}$} & Nome Gênero & Contagem \\
\hline & "Action" & 1 \\
\hline & "Adventure" & 6 \\
\hline & "Biographical" & 1 \\
\hline & "Drama" & 6 \\
\hline & "Mystery" & 1 \\
\hline & "Superhero" & 1 \\
\hline
\end{tabular}

Fonte: (SIMIONATO, CONEGLIAN, GONÇALEZ, SEGUNDO, 2018, p.307)

Um exemplo de uma investigação sobre recursos audiovisuais relacionados a filmes a partir de consulta utilizando uma categoria da DBpedia: uma busca com o nome Marvel Cinematic Universe films, o resultado da consulta dessa classe tem como resultado um conjunto de dados em forma de lista com todas as produções da Marvel Studio e através dessa lista é possível identificar "[...] o músico responsável pela trilha sonora de cada filme, com isso pode-se coletar dados do nome e do nascimento deste músico". (SIMIONATO et al., 2018, p. 307). A figura 2 é uma mostra da consulta feitos pelos autores do caso relatado:

Figura 2: Músicos responsáveis pela trilha sonora de uma série de filmes.

\begin{tabular}{|c|c|c|c|c|}
\hline \multirow{3}{*}{$\begin{array}{l}\text { PREFIX dct: <http://purl.org/dc/terms/> } \\
\text { PREFIX dbo: <http://dbpedia.org/ontology/> } \\
\text { SELECT ?nome_filme ?nome_compositor } \\
\text { ?sobrenome_compositor ?nascimento_compositor WHERE }\{ \\
\text { ?s rdfs:label "Marvel Cinematic Universe films"@en. } \\
\text { ?filmes dct:subject ?s. }\end{array}$} & Nome Filme & $\begin{array}{l}\text { Nome } \\
\text { Compositor }\end{array}$ & $\begin{array}{l}\text { Sobrenome } \\
\text { Compositor }\end{array}$ & $\begin{array}{l}\text { Nascimento } \\
\text { Compositor }\end{array}$ \\
\hline & $\begin{array}{l}\text { "Avengers: Age of } \\
\text { Ultron"@de }\end{array}$ & "Brian"@en & "Tyler"@en & $\begin{array}{l}\text { "1972-05- } \\
08 \text { "^^xsd:date }\end{array}$ \\
\hline & $\begin{array}{l}\text { "Iron Man (2008 } \\
\text { film)"@en }\end{array}$ & "Ramin"@en & "Djawadi"@en & $\begin{array}{l}\text { "1974-07- } \\
19 " \wedge \wedge x s d: \text { date }\end{array}$ \\
\hline \multirow{4}{*}{$\begin{array}{l}\text { ?filmes dbo:musicComposer ?compositor. } \\
\text { ?filmes rdfs:label ?nome_filme. } \\
\text { ?compositor foaf:givenName ?nome_compositor; } \\
\text { foaf:surname ?sobrenome_compositor; } \\
\text { dbo:birthDate ?nascimento_compositor. } \\
\text { \}LIMIT } 10\end{array}$} & $\begin{array}{l}\text { "Thor: } \\
\text { Ragnarok"@en }\end{array}$ & "Mark"@en & $\begin{array}{l}\text { "Mothersbaugh" } \\
\text { @en }\end{array}$ & $\begin{array}{l}\text { "1950-5- } \\
18 " \wedge \wedge x s d: \text { date }\end{array}$ \\
\hline & $\begin{array}{l}\text { "Captain America: } \\
\text { The First } \\
\text { Avenger"@en }\end{array}$ & "Alan"@en & "Silvestri"@en & $\begin{array}{l}\text { "1950-03- } \\
26 " \wedge \wedge x s d: d a t e\end{array}$ \\
\hline & $\begin{array}{l}\text { "Guardians of the } \\
\text { Galaxy } \\
\text { (film)"@en }\end{array}$ & "Tyler"@en & "Bates"@en & $\begin{array}{l}\text { "1965-6- } \\
\text { 5"^^xsd:date }\end{array}$ \\
\hline & $\ldots$ & $\ldots$ & $\ldots$ & $\ldots$ \\
\hline
\end{tabular}

Fonte: (SIMIONATO, CONEGLIAN, GONÇALEZ, SEGUNDO, 2018, p.307)

Apesar do contexto de descrição arquivística conter fragmentações na representação descritiva, mesmo que as práticas do linked data sejam alinhados com a 
descrição arquivística, pois: "[...] Embora as vantagens da descrição arquivística orientada a eventos baseados em LD sejam significativas, há várias preocupações que precisam ser abordadas em qualquer modelo de descrição arquivística que espera incluir materiais audiovisuais." (GRACY, 2018, p. 363, tradução nossa). Disjunções na modelagem da descrição arquivística de LD para imagens em movimento:

4.3.1 Problema 1. Desassociação da informação e contexto dos materiais arquivísticos.

O LD tende a quebrar a documentação do arquivamento em pedaços discretos de informações e relações individuais entre o sujeito e o objeto. Muitos arquivistas podem argumentar que uma única declaração sujeito-objeto-predicado expressa como um RDF triplo, como "John Smith é o operador de vídeo para este segmento de vídeo", pode ajudar a obter mais informações sobre John Smith e o segmento de vídeo descrito, mas faz pouco para ajudar os usuários a colocar essas informações em um contexto maior. Essa atomização do registro descritivo arquivístico pode alcançar o oposto do que a descrição arquivística pretende fazer - efetivamente descontextualizando o registro da imagem em movimento.

Como os sistemas de informação podem manter várias partículas de descrição arquivística associadas a um criador, trabalho, coleção ou evento conectado, para permitir uma contextualização mais completa quando necessário? (GRACY, 2018, p.363, tradução nossa)

Dessa forma, Gracy (2018, p. 363, tradução nossa) conclui que novas ferramentas podem ser necessárias para auxiliar os usuários a navegar pelos dados e relacionamentos entre entidades. Podendo usar técnicas transdimensionais, que possibilitam que ferramentas como SPARQL façam inferências entre diferentes recursos, "[...] como a visualização de várias declarações de informações associadas a uma entidade, o que permitiria aos arquivistas comunicar as complexidades e interconexões de imagens em movimento aos usuários".

4.3.2 Problema 2: descrição no nível "subatômico". Os modelos de dados de descrição audiovisual arquivísticos atuais ou sugeridos não suportam a descrição de material no nível fragmentário. Como Lyons e Van Malssen (2016) observam, "descrições completas de estruturas de subinstâncias (por exemplo, faixas, fluxos de bits, fluxos de arquivos, quadros, componentes) devem ser tratadas em profundidade por preservação e namespaces específicos de audiovisual fora de o contexto bibliográfico". Assim, é responsabilidade dos arquivistas audiovisuais que considerem que esse nível de detalhe mais granular é importante para desenvolver esses vocabulários, namespaces e sistemas para descrever completamente além do nível da instância. Esta descrição subatômica é particularmente importante para atividades de preservação e reutilização.

4.3.3 Problema 3: lacunas de vocabulário. O campo da imagem em movimento é deficiente em vocabulários controlados e ontologias para a descrição centrada em evento que permitiria a contextualização completa do conteúdo da imagem em movimento por meio de fases / fases do ciclo de vida ou por todo o continuum da manutenção de registros [...]. (GRACY, 2018, p. 363, tradução nossa)

O lançamento de um projeto Linked (Open) Data pela FIAF, com a participação de autores de várias instituições como a Cineteca de Bolonha, Cinémathèque Royal de 
Belgique e a British Film Institut, é uma iniciativa das oficinas da FIAF 2017, onde a Comissão de Catalogação e Documentação da FIAF (CDC) formou uma força tarefa sobre Linked Open Data que identificou duas áreas para abordar o LOD: O Manual de Catalogação de Imagens em Movimento da FIAF e os Glossários de Termos Técnicos e Filmográficos da FIAF.

Construído na EN 15907, o Manual da FIAF estabelece as bases para uma praxis de catalogação baseada em padrões. O objetivo do projeto LOD é a) criar uma Ontologia que represente os direitos e relações no Manual de Catalogação da FIAF e b) transformar os Glossários FIAF de termos Técnicos e Filmográficos em um conjunto de dados LOD mais formalizado (FIACCARINI; BIESBROUCK; MACCONNACHIE, 2017, tradução nossa)".

Ainda segundo os autores, tomados em conjunto como recursos-chave de informação da FIAF, o Manual e os Glossários são uma área onde o Linked Open Data pode progredir os recursos de forma a torná-los úteis para a comunidade de arquivo de filmes no século XXI. A intenção é que o projeto LOD seja gerenciado com a contribuição da comunidade e possivelmente hospedado pela FIAF. Os objetivos do projeto de Dados Abertos Vinculados da Comissão de Catalogação e FIAF são:

Figura 3: Usando o SKOS (Simple Knowledge Organization System) ou outro modelo para codificar vocabulários controlados como LOD

\begin{tabular}{|l|l|l|l|l|l|}
\hline \multicolumn{1}{|c|}{ Concepts } & Labels \& Notation & Documentation & Semantic Relations & Mapping Properties & \multicolumn{1}{c|}{ Collections } \\
\hline Concept & prefLabel & note & broader & broadMatch & Collection \\
\hline ConceptScheme & altLabel & changeNote & narrower & narrowMatch & orderedCollection \\
\hline inScheme & hiddenLabel & definition & related & relatedMatch & member \\
\hline hasTopConcept & notation & editorialNote & broaderTransitive & closeMatch & memberList \\
\hline topConceptOf & & example & narrowerTransitive & exactMatch & \\
\hline & & historyNote & semanticRelation & mappingRelation & \\
\hline & & scopeNote & & & \\
\hline
\end{tabular}

Fonte: FIAF Cataloguing and Documentation Commission'sLinked Open Data project 
Figura 4: odificação LOD de vocabulários em Glossários Filmográficos e Técnicos, para uso em ontologia:

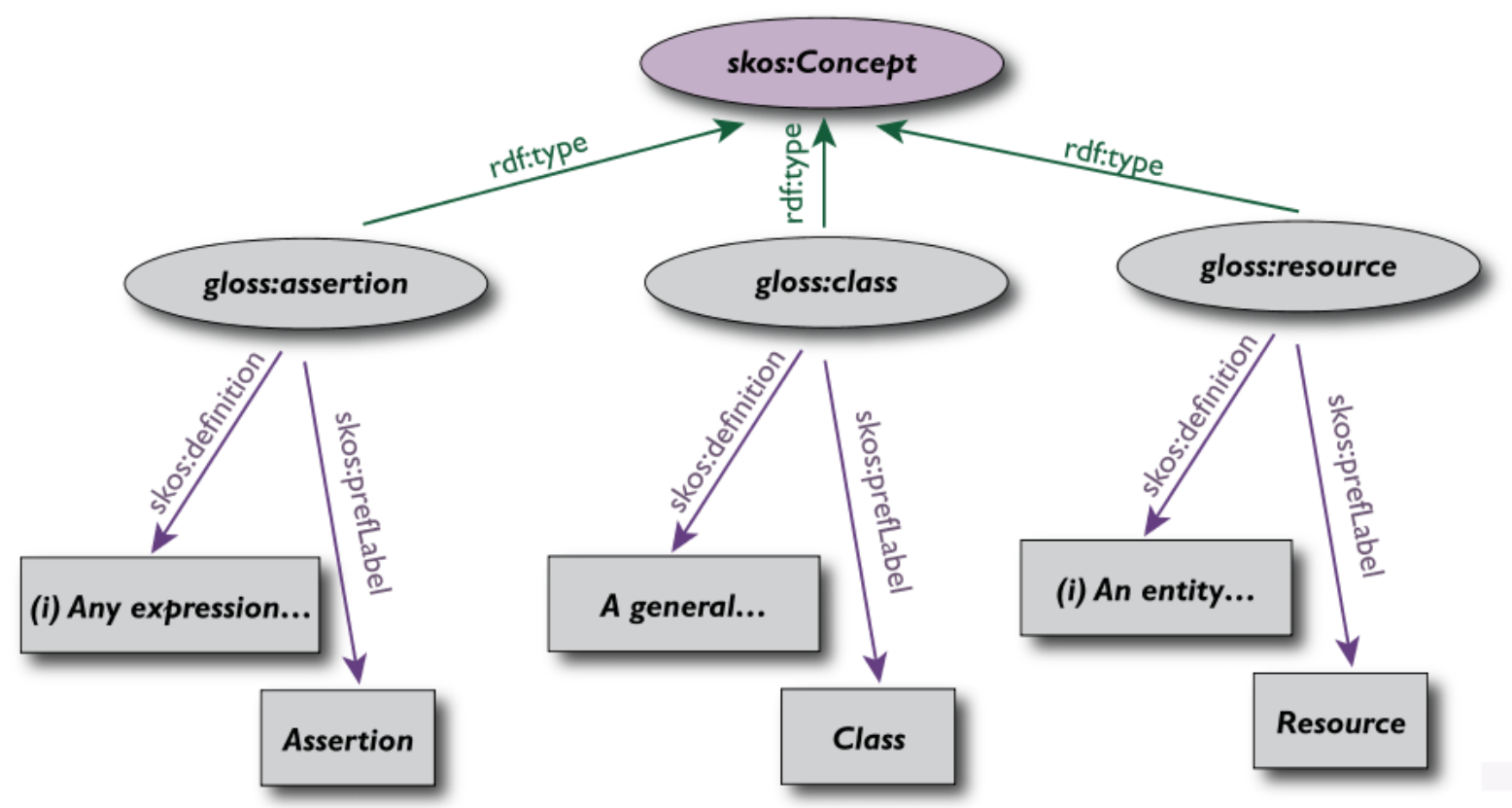

Fonte: FIAF Cataloguing and Documentation Commission’sLinked Open Data project 
Figura 5: Grafos RDF da tripla de um filme.

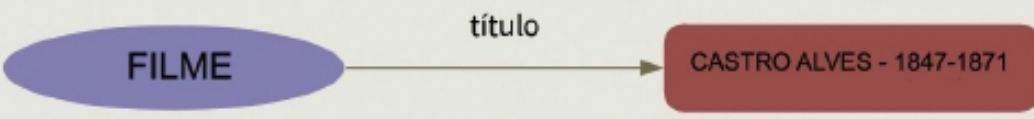

Fonte: adaptado de CEWEB (2015).

Figura 6: GRAFO RDF genérico de uma tripla

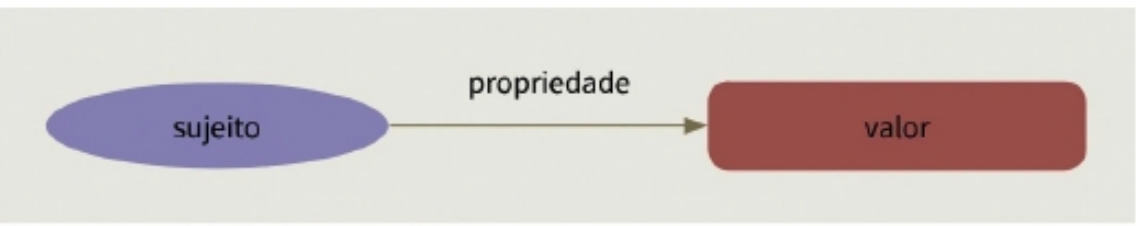

Fonte: adaptado de CEWEB (2015).

Figura 7: GRAFO RDF com três triplas de um mesmo recurso.

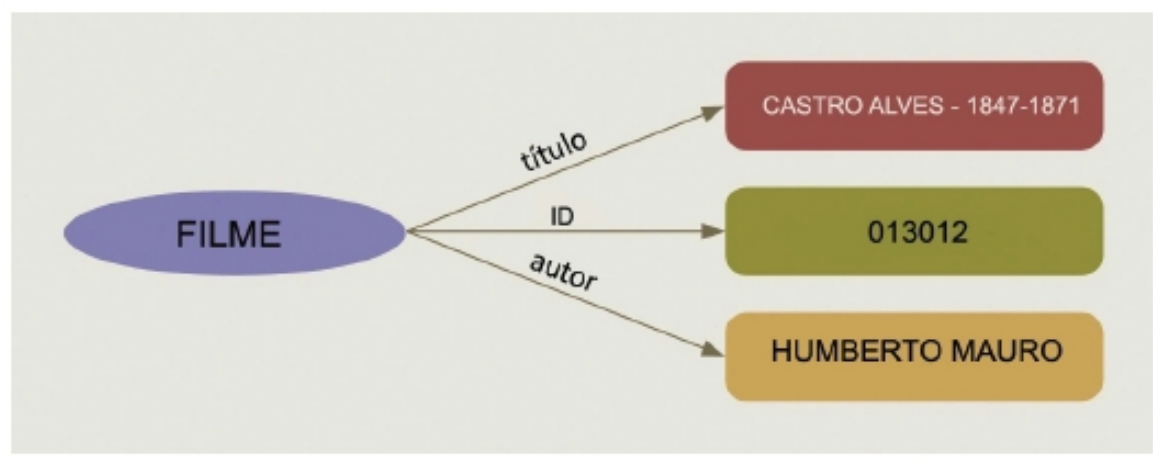

Fonte: adaptado de CEWEB (2015). 
Figura 8: GRAFO RDF relacionando recursos.

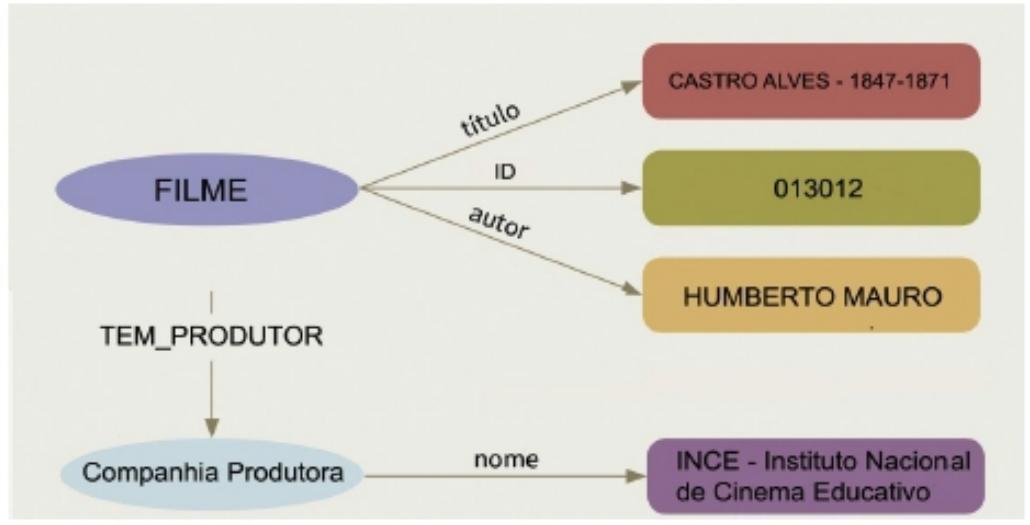

Fonte: adaptado de CEWEB (2015).

Figura 9: Representa ligações entre recursos que representam uma mesma informação.

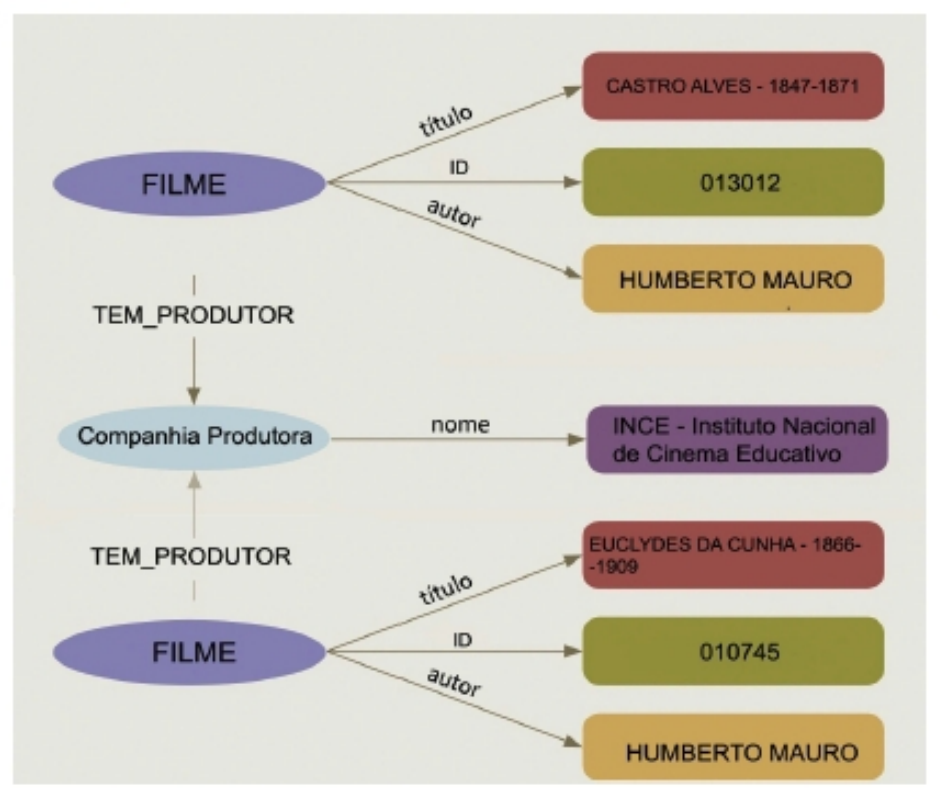

Fonte: adaptado de CEWEB (2015). 
Figura 10: GRAFOS URI

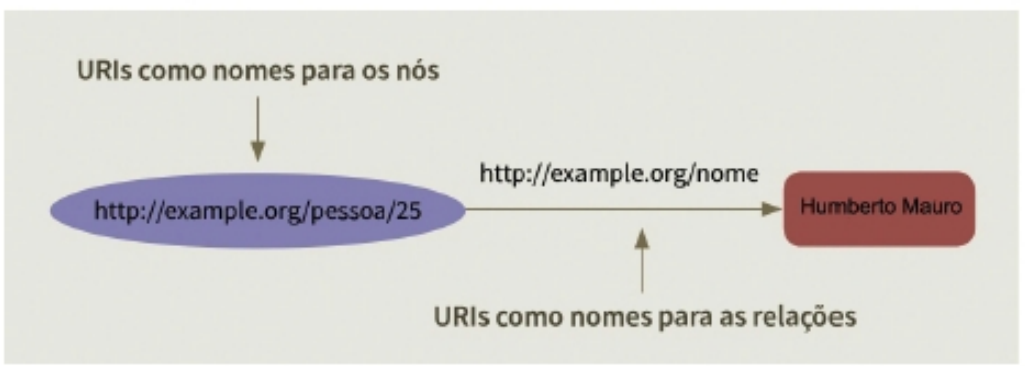

Fonte: adaptado de CEWEB (2015).

Figura 11: Exemplo de uso de foaf:name

http://xmlns.com/foaf/0.1/name

http://example.org/pessoa/25 $\longrightarrow$ Humberto Mauro

Fonte: adaptado de CEWEB (2015). 


\title{
4.4 Projetos e iniciativas internacionais para audiovisual e Linked Data
}

\section{Knowledge Graph Google}

Com o advento do linked data, foi proposto interligar diferentes conjuntos de dados na Web Semântica. Por meio de interligação, a coleta de dados poderia ser entendida como um grande gráfico de conhecimento global (embora de natureza muito heterogênea). Até o momento, cerca de 1.000 conjuntos de dados estão interligados na nuvem Linked Open Data, com a maioria dos links conectando entidades idênticas em dois conjuntos de dados (PAULHEIM, 2017, p. 490).

\begin{abstract}
O potencial desse aprimoramento e enriquecimento já pode ser visto por meio de modelos de pesquisa da próxima geração, como o Knowledge Graph do Google, que "entende entidades do mundo real e seus relacionamentos: coisas, não cordas" (Singhal, 2012). Uma pesquisa simples por uma entidade reconhecível, como uma pessoa, organização, local, evento, publicação ou obra de arte, invoca o modelo de pesquisa inteligente do Knowledge Graph. Como parte dos resultados da pesquisa, o mecanismo retornará um resumo das informações relacionadas a essa entidade; por exemplo, uma pesquisa pelo título "O lluminado" retornará informações relacionadas ao Stanley Filme de Kubrick, incluindo o ano de lançamento, diretor, roteirista, membros do elenco, uma sinopse do enredo, imagens do filme, um link para o trailer encontrado no YouTube, avaliações de vários sites de filmes na Internet como Rotten Tomatoes, listagens de programas para quando veja o filme na televisão ou em sites de streaming, onde comprar o filme on-line e recursos relacionados, como o romance de Stephen King no qual o filme se baseia. Embora algumas dessas informações sejam provenientes da base de conhecimento do Google (muitas delas são coletadas por fontes de dados de código aberto, como DBpedia), outras informações são extraídas de fontes como provedores de dados como Amazon e provedores de serviços de dados como Rovi (GRACY, 2017, p.355, tradução nossa).
\end{abstract}

\section{BIBFRAME}

No campo da Ciência da Informação destaca-se o Bibliographic Framework (BIBFRAME) um novo modelo de dados que favorece a descrição formal dos relacionamentos existentes entre os recursos por meio de links, indo ao encontro das novas tendências de pesquisas como: linked data; Data Science; Publicação Ampliada e Web Semântica (RAMALHO, 2016, p. 293).

Para avaliar o BIBFRAME na perspectiva do arquivamento audiovisual foi encomendado pelo Gabinete de Desenvolvimento e Padrões da Rede da Biblioteca do Congresso

"para avaliar as necessidades de descrição de conteúdo da imagem em movimento e comunidades de som gravadas e para especificar como esses requisitos podem ser satisfeitos num modelo de dados bibliográficos semânticos concebidos genericamente 
para apoiar todos os tipos de conteúdo encontrados nas bibliotecas "(VAN MALSSEN, 2014, p. 3).

\section{Harvard Film Archive/ Moving Image Resources}

À medida que as ferramentas são desenvolvidas, o projeto avaliará a eficácia do BIBFRAME / LD4L como um modelo de dados para descrever materiais de imagens em movimento para necessidades de pesquisa e identificar vocabulários específicos para a descrição desses materiais em um ambiente de dados vinculados. O projeto da HFA criará mapeamentos para registros do banco de dados de impressão de filmes da HFA, concentrando-se em um subconjunto de materiais de imagens em movimento de diretores mulheres (trabalho que já foi subexposta e, em muitos casos, exclusivo dessa coleção). Sempre que possível, as entidades serão reconciliadas com URIs de dados vinculados, incluindo nomes pessoais e corporativos (ISNI, LCNAF), nomes de lugares (GeoNames), gêneros (gênero / formulário LC, Getty AAT) e trabalhos (Harvard University Library Technology Services, 2017). 


\section{Proposta: Organização de dados para recuperar informações sobre textos e arquivos de filmes universitários: uma aplicação ao acervo de TCCS do Curso de Audiovisual da Biblioteca da ECA}

\subsection{Estudo de Caso}

A pesquisa tem como estudo de caso os trabalhos de conclusão de curso de alunos da ECA/USP dos cursos de audiovisual, Jornalismo e Artes Visuais, que fazem parte do catálogo Trabalhos de Conclusão de Curso ECA/USP e segundo informação impressa no catálogo estão listados trabalhos de conclusão de curso de alunos da ECA/USP realizados em forma de reportagens, filmes, videoarte e outras formas de linguagem audiovisual.

A totalidade do acervo de filmes, vídeos e DVDs está registrada em bases de dados online: Dédalus - Banco de Dados Bibliográficos da USP, catálogo de todas as bibliotexas da USP. Ainda não traz a totalidade do acervo audiovisual da ECA.

http://200.144.190.234/f

Filmes e Vídeos, catálogo específico desse acervo, completo, disponível no site da Biblioteca da ECA:

http://www.eca.usp.br/biblioteca-bases/cena/search.htm

\subsubsection{Descrição do objeto empírico: TCCS: Descrição do corpus (conjunto de documentos)}

\subsubsection{Recorte TCCs e Biblioteca da ECA (open biblioteca/ exemplo: acervo obras de artes)}

Segundo o manual de catalogação de filmes da ECA (MACAMBYRA, 2009, p. 1) o acervo de imagens em movimento da Biblioteca da ECA/USP é formado por diferentes tipos de documentos: filmes importantes do cinema nacional e internacional; produções dos alunos do Curso Superior de Audiovisual da ECA; teses e trabalhos de conclusão de curso; óperas e outros documentos musicais, filmes publicitários; trabalhos de videoarte; programas de televisão; documentários que abordam assuntos relacionados às áreas de estudo da Escola e de apoio às atividades de ensino e pesquisa:

A formação do acervo obedece a critérios relacionados à importância do documento no contexto da história do cinema ou da televisão mundial e às necessidades dos programas das diversas disciplinas que utilizam esse tipo de material. Critérios que envolvem, portanto, questões de qualidade e de utilidade prática. 
A coleção tem sua origem no material da própria Escola, que produz filmes desde 1968. Seu crescimento acelerou-se a partir do ano de 1987 quando a Biblioteca começou a comprar material audiovisual de forma sistemática, medida que tornou possível o desenvolvimento da coleção de vídeos destina ao uso didático pelos cursos da Escola. A popularização do videocassete, tecnologia que facilitou o processo de captação de imagens, aumentou significativamente, no decorrer da década de 1990, a quantidade de trabalhos acadêmicos que chegavam à Biblioteca acompanhados por trechos de filmes ou filmes completos, registro de experiências, depoimentos e entrevistas com imagens etc.

Através de pesquisa in loco verificou-se que o acervo audiovisual da Biblioteca da ECA é organizado por catálogos temáticos que podem ser acessados na biblioteca para consulta sobre a obra e o item. Os catálogos de filmes são organizados pelos seguintes temas: Dança, Ópera, Futebol, Documentários de Arte, Filmes acessíveis (audiodescrição e closed caption), Mostra Exploratória do Acervo de DVDs, Mulheres, Ficção Científica, São Paulo em filmes, Consciência Negra, Educação, Vingança, Trabalho e Trabalhadores, Revoluções, Filmes Japoneses, Corporalidade, ANCINE, Série Nacionais, Comédia, Animação, Viagens, Terror, Filmes Legais, 65 Filmes Dirigidos por Mulheres, Filmes Premiados do Curso de Audiovisual e Trabalhos de Conclusão de Curso ECA/USP.

A Biblioteca é depositária de 10.353 partituras, 11.000 gravações, 20.000 slides, 2500 fotos, 328 filmes em película, 1700 vídeos e 71 CD-ROMs multimídia. O tipo de material da amostragem são Trabalhos de Conclusão de Curso em suporte audiovisual dos cursos de jornalismo, artes visuais e audiovisual nos seguintes suportes: vídeo : 1 ex., VHS/NTSC, col e DVD: 1 ex., NTSC, col.

O período que abrange o recorte do objeto de pesquisa e forma o corpus empírico é de 1992 até 2017. Os suportes do material que formam a amostra são o VHS-Video Home System (Sistema Doméstico de Vídeo), padrão comercial e gravação analógica em fitas e o DVD-Digital Video Disc"(Disco Digital de Vídeo), padrão comercial e formato digital. O tamanho da amostragem é a quantidade de obras resultante da pesquisa pelo termo TCC que são 184 documentos de imagem em movimento.

Pesquisando por: DVD tem 5276 resultados.

Pesquisando por: DVD AND TCC tem 131 resultados.

Pesquisando por: VHS tem 177 resultados.

Pesquisando por: VHS AND TCC tem 11 resultados.

Pesquisando por: FICÇÃO tem 2720 resultados

Pesquisando por: TCC AND FICÇÃO: 17 resultados.

Pesquisando por: DOCUMENTÁRIO tem 1611 resultados

Pesquisando por: TCC AND DOCUMENTÁRIO: 113 resultados.

Pesquisando por: VIDEOARTE tem 34 resultados 
Pesquisando por: TCC AND VIDEOARTE: 4 resultados.

\subsubsection{Metadados, formas de descrição e representação temática da Biblioteca da ECA}

O Departamento de Cinema, Rádio e Televisão é um órgão ligado à Biblioteca às práticas documentais, essa relação começou concomitantemente ao tratamento da informação de filmes da Biblioteca da ECA.

"A necessidade de criar um catálogo de filmes que atendesse as necessidades do público principal do acervo, ou seja, profissionais, estudantes e pesquisadores de cinema, levou a uma decisão importante: desenvolver normas locais de catalogação" (MACAMBYRA, 2009, p. 1):

o Código Anglo-Americano de Catalogação - $2^{\mathrm{a}}$ edição (AACR2), padrão usado pela Biblioteca no tratamento de documentos textuais, não trazia respostas adequadas às questões específicas do tratamento de imagens em movimento, especialmente quando se considerava o perfil do público e a forma de utilização do acervo. Filmes não são livros, e tratá-los como se fossem não resolve o problema.

De acordo com Ferreira (2011, p. 74) a representação dos materiais da Biblioteca da ECA sempre teve como foco principal o público do acervo e sempre ocorreu uma preocupação com o desenvolvimento de normas locais de catalogação e em relação ao uso do FRBR e a nova norma RDA a Biblioteca da ECA se aproxima da prática adotada pelo novo código visto que "la principal diferencia entre la metodología de la ECA y las reglas del Código de Catalogación Anglo americano, $2^{a}$ edición (AACR2) está en la unidad de tratamiento". Macambyra (2009, p. 74) explica que:

A distinção fundamental entre a metodologia da ECA e as regras do AACR2 está na unidade de tratamento. Enquanto o AACR2 trata o "item em mãos", na Biblioteca da ECA nossa referência principal é a obra cinematográfica contida no documento catalogado, que é, quase sempre, o interesse principal dos usuários. $E$ são precisamente os dados da obra, seja ela qual for, filme ou telenovela, que as regras do AACR2 deixam muitas vezes "escapar" da descrição.

Além da representação dos materiais da Biblioteca da ECA anteciparem as práticas adotadas do modelo conceitual FRBR e do código RDA, ele também se adiantou em relação à última atualização do Manual de Catalogação da FIAF (2016), visto que na época da publicação do Manual de Catalogação de filmes da Biblioteca da ECA (2009) apenas existia a publicação FIAF Cataloguing Rules (1991) e o FRBR foi publicado em 1998 pela International Federation of Libraries, sendo também o Manual de Catalogação de filmes da Biblioteca da ECA contemporâneo ao desenvolvimento da (CEN) Cinematographic Works Standard EN 15907 que também só foi inserido no manual na revisão da FIAF (2016). 
Um estudo, realizado em conjunto com os alunos da disciplina Multimeios, da professora Johanna Smit do curso de Biblioteconomia da ECA, teve como resultado o primeiro modelo de ficha matriz de filmes e aos básicos do tratamento da informação para o acervo. Para construir um conjunto de regras, foi realizado análise das experiências e os hábitos dos usuários e usado exemplos de fichas de outros acervos de imagens em movimento (MACAMBYRA, 2009).

O grande volume de coleções de documentos audiovisuais é uma característica marcante e uma das mais importantes da Biblioteca da Escola de Comunicações e Artes da USP. "Imagens em movimento, imagens fixas, partituras musicais e documentos sonoros correspondem a mais de 40 por cento do acervo processado". Visto que a Escola de Comunicação e Arte da USP oferece cursos de música, cinema, artes plásticas, televisão e publicidade, esses documentos equivalem a uso de livros e textos para o campo da pesquisa acadêmica e atividades de ensino (MACAMBYRA, 2001, online).

Atualmente, a Biblioteca possui 10.353 partituras, 11.000 gravações, 20.000 slides, 2500 fotos, 328 filmes em película, 1700 vídeos e 71 CD-ROMs multimídia. Esse acervo é formado por doações, material comprado com verbas da Universidade e de convênios, e também por produção própria: a Biblioteca produz slides para uso didático, fotografando ilustrações em livros e catálogos de exposições, e grava em CD seus discos de vinil, para facilitar sua utilização. O usuário desses materiais tem à sua disposição espaços planejados para consulta, com dois pequenos auditórios, um para áudio e um para vídeo, além de equipamentos com fone de ouvido para uso individual. O acervo está armazenado em ambiente adequado, que inclui uma sala com temperatura e umidade controladas para os filmes, vídeos e documentos fotográficos. Foram desenvolvidas três bases de dados específicas para cadastramento das partituras, imagens em movimento e gravações, todas acessíveis pela página da Biblioteca na internet (www.rebeca.eca.usp.br).

Posteriormente, com o crescimento do acervo foram incorporados informação e dados de revistas especializadas, dicionários da área e no material promocional das produtoras, sempre observando como esses dados eram dispostos. "Mas a maior fonte de aperfeiçoamento do sistema continuou sendo a opinião do usuário, suas críticas e sugestões" (MACAMBYRA, 2009). Segundo Ferreira (2011, p. 77) o processamento da informação realizada pela Biblioteca da ECA nos documentos audiovisuais é muito detalhado:

las películas son vistos en su totalidad para la preparación de los resúmenes, los discos son catalogados e indexados pista por pista y las colecciones de música, obra por obra, los intérpretes de la dirección musical y personal de las películas se registran en bases de datos, los documentos están indexados por los instrumentos musicales. Para el registro de las partituras, grabaciones y películas se desarrollaron tres bases de datos específicas, todas accesibles desde la página web de la Biblioteca en Internet 


\subsubsection{Coleta de dados e levantamento do material}

Pesquisando na base de dados CENA da Biblioteca da ECA não é possível realizar uma busca separada pelos cursos da instituição que são produtores de imagem em movimento. Por tais motivos, optou-se primeiramente por uma busca mais genérica pelo termo de busca TCC que obteve 184 resultados. Foram analisadas as obras e verificou-se que o total da busca possui itens com o campo denominado "materiais" nos seguintes suportes: vídeo : 1 ex., VHS/NTSC, col e DVD : 1 ex., NTSC, col. Os TCCs do curso de jornalismo são a maioria na base de dados cena e podem ser identificados através do campo de produção pelo código ECA-USP-CJE. Os TCCs do curso de Artes Visuais podem ser identificados através do campo de produção pelo código ECA-USP-CAP. Os tcc do curso de Audiovisual são identificados no campo denominado "produção" pelo código ECA-USP-CTR. Dessa forma uma busca pesquisando por:

Pesquisando por: TCC AND 2005. Resultado: 10

Pesquisando por: TCC AND 2009, o número de resultados da pesquisa é 10. 8 produções ECA-USP-CJE e 2 produções sem identificar qual curso ela pertence apenas o campo que indica que faz parte de tcc.

Pesquisando por: TCC AND 2010, o número de resultados da pesquisa é 13, sendo 12 produções ECA-USP-CJE e apenas uma produção ECA-USP-CTR.

Pesquisando por: TCC AND 2011, o número de resultados da pesquisa é 20. Não aparece filmes, vídeos ou outra imagem em movimento em suporte de CD-rom

Pesquisando por: TCC AND 2012. Resultado: 07

Pesquisando por: TCC AND 2013. Resultado: 06

Pesquisando por: TCC AND 2014. Nenhum registro encontrado!

Pesquisando por: TCC AND 2015. Resultado: 04

Pesquisando por: TCC AND 2016. Nenhum registro encontrado!

Pesquisando por: TCC AND 2017. Resultado: 01

Alguns dos assuntos do catálogo de Trabalhos de Conclusão de Curso ECA/USP são:

1. Arquitetura - Brasil - Século 20; Arquitetos.

2. Vida cotidiana; Vila do Bonete (Cidade / São Paulo); Pescadores.

3. Jornalismo - Brasil; Comunicação visual; Telejornalismo.

4. Cidades; Segurança no trânsito; São Paulo (Cidade / Brasil).

5. Teatro - Brasil - Século 20.

6. Água; Abastecimento de água; Consumo de água.

7. História da Argentina; Exilados.

8. Computação gráfica; Telejornalismo - Brasil; Efeitos especiais (Televisão).

9. Crianças; Trabalho de menor; Brasil.

10. Dança; Balé; Dançarinos; Companhias de dança - Brasil - São Paulo (SP).

11. Doentes; AIDS. 
12. Museus - São Paulo.

13. Internet (Rede de computadores); Design.

14. Crise econômica - Cuba.

15. Piratas; Programas infantis (Televisão); Contos de fadas.

16. Estudantes; Jovens; Faculdade.

17. Crianças; Mães; Vizinhos.

18. Crianças; Pais; Família; Deficiente mental.

19. Morte.

20. Crime.

21. Televisão - Produção e direção; Transmissão ao vivo.

22. Adolescentes.

23. Casais; Fantasias; Alucinações.

24. Morte; Natal; Crianças.

25. Trabalho.

26. Música - aspectos psicológicos; Linguagem musical - aspectos psicológicos; Som (Música) - aspectos psicológicos.

27. Som (Música); Morte.

28. Família; Mães; Fotografia; Relações familiares.

29. Mulheres; Gravidez; Loucos; Hospitais; Praças; São Paulo (Cidade / Brasil).

30. Século 21; Meninas; Crianças.

31. Amazônia (Região / Brasil); Mamirauá (Região / Brasil); Costumes - Amazônia; Ecologia.

32. Samba; Músico.

33. Literatura brasileira; Os sertões (livro).

34. Desmatamento - Rondônia (Estado / Brasil).

35. Deficientes físicos.

36. Idosos; Trabalho; Trabalhador idoso.

37. História da música -América Latina - Século 20; Música popular; Canção de protesto.

Figuras 12 e 13 : Interface de consulta Base CENA

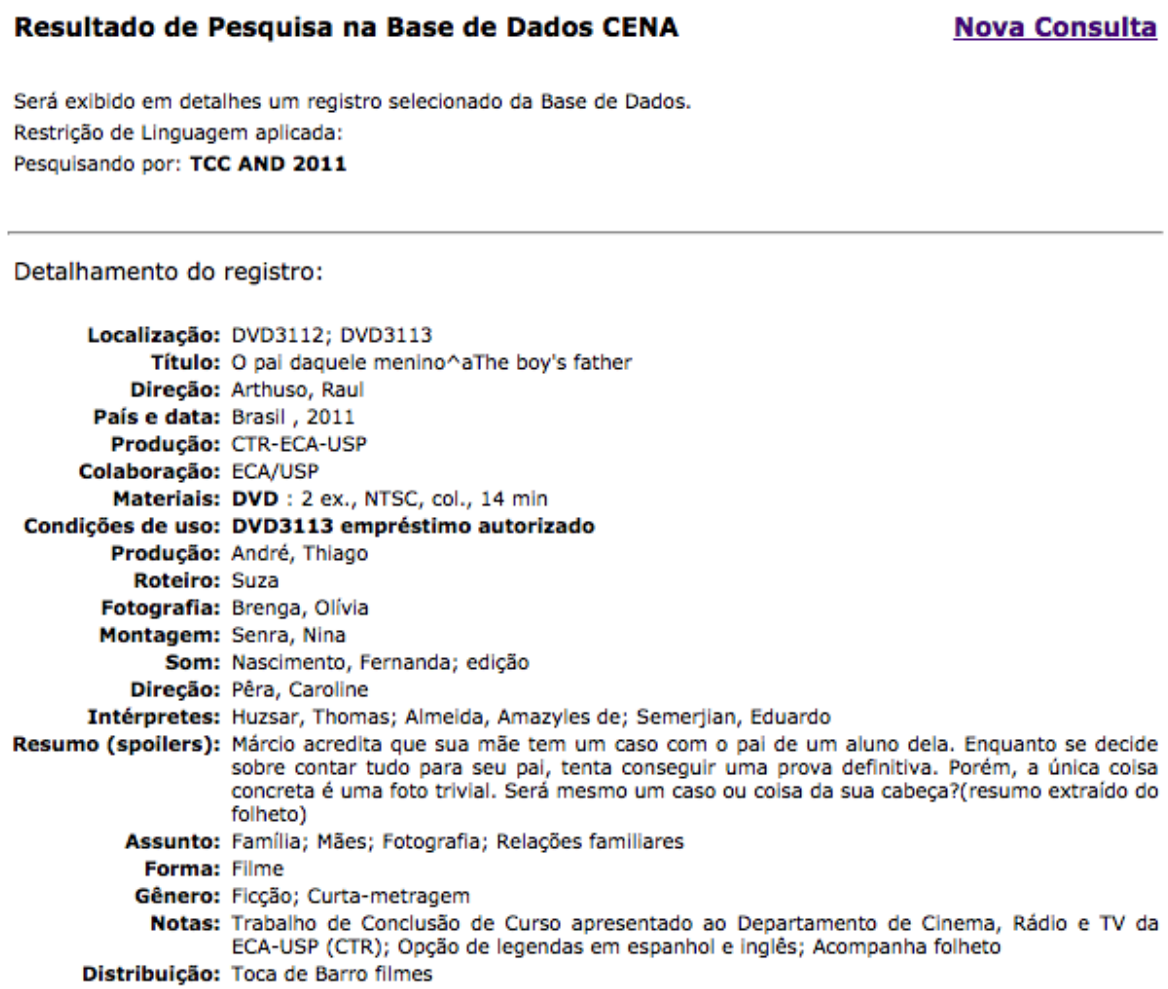



Será exibido em detalhes um registro selecionado da Base de Dados.
Restrição de Linguagem aplicada: Pesquisando por: TCC AND 2011

Detalhamento do registro:

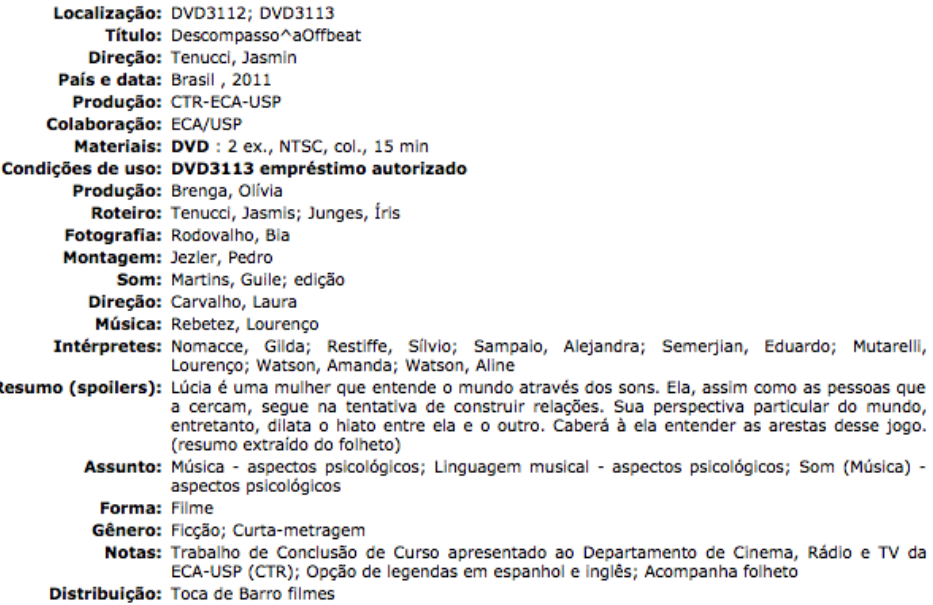

Figura 14: Catalogação de filme da Biblioteca da ECA

\section{- Trabalho de conclusão de curso de aluno da ECA/USP}

Localização: DVD0373

Título: Antes, um dia, e depois: oito histórias de mudança e incerteza

Direção: CAVECHINI, Caio

Autoria: CINTRA, José Roberto; orientação

País: Brasil , 2005

Produção: ECA-USP-CJE

Materiais: DVD : 1 ex., NTSC, col., 95 min

Produção: CAVECHINI, Caio

Roteiro: CAVECHINI, Caio

Fotografia: CAVECHINI, Caio

Edição: CAVECHINI, Caio

Parte do TCC: CAVECHINI, Caio. Antes, um dia, e depois: oito histórias de mudança e incerteza

Resumo: Acompanha o momento em que oito pessoas passam por transformações decisivas em suas vidas. São registradas as experiências, reações e reflexões dos seguintes personagens: romeiro que chega à Basilica de Aparecida cumprindo uma promessa pela saúde da filha; prefeito não reeleito em seu último dia de trabalho numa cidade no interior de São Paulo; trabalhador escravizado voltando para casa, depois de ser libertado; Dom Pedro Casaldáliga no dia da posse de seu sucessor como bispo na região do Araguaia; casal prestes a se mudar da propriedade da familia do marido; sargento antes de embarcar para o Haiti como integrante da missão de paz da $\mathrm{ONU}$; familia de Joinville preparando-se para receber duas meninas em adoção; transexual antes e depois da cirurgia de mudança de sexo.

Descritores de assunto: Experiências de vida; Religiosidade popular; Trabalhadores; Bispos; Militares; Familia; Transexuais

Forma: Video

Gênero: Documentário

Fonte: Macambyra (2009, p.52) 


\section{Discussão dos resultados}

Os resultados qualitativos demonstraram que existem pesquisas sobre representação temática e descritiva no contexto da Ciências da Informação que consideram os desafios e demandas trazidas pelas tecnologias da informação em ambientes digitais, como a criação e atualização de instrumentos mais adaptados para o contexto de rápida produção de conteúdo, intensa digitalização dos processos e suportes, participação ativa de usuários e instituições na web.

A representação temática demonstrou existir um paralelo entre os instrumentos de $\mathrm{Cl}$ e as práticas da web semântica, como os tesauros que são utilizados em campos que se referem ao conteúdo, apesar de não serem usados para definir conceitos e sim a estrutura, termos e relacionamentos a partir de tecnologias como SKOS e OWL através de ontologias, geralmente criados para uma aplicação específica (BOCCATO; RAMALHO; FUJITA, 2008).

Já a representação descritiva se refere ao conteúdo de dados muitas delas se desenvolveram de acordo as novas demandas do digital e da web, a tendência que isso continue acontecendo alinhando cada vez mais normas e padrões as iniciativas do W3C e sua proposta de um modelo de descrição de recursos da Web, o Resource Description Framework (RDF) que é fundamental para a Web Semântica.

A descrição de recursos audiovisuais no cenário da web semântica e a LD ainda caminha lentamente visto que muitos instrumentos usados para descrição bibliográfica precisam ser atualizados de forma que possam melhorar os campos e os relacionamentos com maior cobertura de conteúdo de dados e conteúdo, além da criação de catálogos dinâmicos com links externos.

Desse modo evidenciou-se que existem esforços para que os recursos audiovisuais acompanhem os próximos passos, existindo um grupo de profissionais e instituições do campo da organização, preservação e recuperação de recursos audiovisuais que estão pesquisando soluções para gerenciamento de metadados e desafios de catalogação, sendo a expertise acumulada pelos profissionais de $\mathrm{Cl}$ e instituições como bibliotecas e arquivos no campo de normas e documentação sobre organização da informação um diferencial para encontrar formas em que os usuários possam realizar buscas semânticas a partir de agente computacionais. 
A parte empírica que foi propor um conjunto de indicativos para preparar instrumentos de recuperação de filmes universitários da biblioteca da ECA dentro do contexto do linked data., que auxiliem futuras pesquisas que coloquem em prática o alinhamento das normas locais da Biblioteca da ECA presente no Manual de Catalogação de Filmes e catálogo da Base CENA com os princípios da web semântica e linked data. Os resultados da parte empírica tiveram as seguintes etapas: mostraram que o catálogo de filmes e o manual de filmes da Biblioteca da ECA são resultados de trabalhos dos profissionais da ECA que estão em sintonia com os usuários e dessa forma a parte de representação descritiva e os catálogos por temas evidenciam que a primeira parte (que é o conteúdo dos dados) das metodologias e procedimentos para a criação de instrumentos de recuperação de filmes da ECA utilizando o LD está adiantada, visto que o tratamento feito pelos bibliotecários mostra-se avançado dentro das questões aqui discutidas, partindo da perspectiva que ainda muitas instituições com acervos audiovisuais acadêmicos não tratam seus documentos audiovisuais nos parâmetros da organização da informação ou tratam com livros. Outro motivo é o fato do MARC 21 e o modelo FRBR serem muitos explorados eles estão entre os instrumentos atualizados dentro do contexto LD, tendo a biblioteca optado pela aplicação da FRBR o que possibilitaria usar FRBR (em combinação com termos em Dublin Core) para a descrição estruturada de entidades bibliográficas, mesmo que para recursos audiovisuais existam menos datastes e iniciativas, mesmo que metodologias e instrumentos para estruturar os recursos audiovisuais com linked data ainda não foram construídos e finalizados, como o grupo de trabalho da comunidade de catalogadores audiovisuais da FIAF Cataloguing and Documentation Commission's Linked Open Data project, que está trabalhando no escopo e desenvolvimento de recursos LOD com plano de trabalho até 2020.

Dessa forma, ficou constatado que como citado na hipótese de trabalho para conseguir construir e aplicar o conjunto de indicativos para preparar instrumentos de recuperação de filmes universitários da biblioteca da ECA dentro do contexto do Linked Data é preciso realizar estudo de usuário para saber quais termos usuários estão buscando e quais já existem no vocabulário, problemas nos termos, qual parte do documento, se é local, o tema, algum agente ou alguma relação entre entidades, uma sequência especifica ou uma imagem, o que os usuários estão buscando quando procuram o acervo. 
Por tais motivos, a pesquisa se pauta no referencial teórico e nos objetivos do projeto de Dados Abertos Vinculados da Comissão de Catalogação e FIAF para identificar caminhos possíveis para pautar a construção de um futuro conjunto de indicadores para atualizar os catálogos de filmes da Biblioteca da ECA para ambientes mais dinâmicos:

1-Mapeamento e alinhamento dos Campos MARC 21 e dos relacionamentos do modelo conceitual FRBR do grupo 1 para metadados como Dublin Core, vocabulário FOAF, e $R D F$.

O quadro (MACAMBYRA, 2009 apud FERREIRA, 2011) abaixo foi adaptado do original acrescentando-se a coluna de metadados Dublin Core como exemplo sucinto e bem simples de como é possível mapear as entidades, atributos e relacionamentos para outros instrumentos mais adequados para estruturas dados em RDF, ontologias e esquemas de organização do conhecimento, mesmo que isso não se dê de forma equivalente, ou seja, esse mapeamento entre instrumento apresentam mais disjunções que equivalências. 
Tabela 3: Mapeamento dos campos do recurso da figura 13.

\begin{tabular}{|c|c|c|c|}
\hline Base CENA & Marc 21 & Dublin core & FRBR \\
\hline Identificadores & 035_|9 DVD3112 & $\begin{array}{l}\text { <dc:identifier> } \\
\text { DVD3112</dc:iden- } \\
\text { tifier> }\end{array}$ & \\
\hline Título Original & $\begin{array}{l}245^{a} \_\mid \text {O pai } \\
\text { daquele menino } \\
\text { 245b_l O pai } \\
\text { daquele menino }\end{array}$ & $\begin{array}{l}<\text { dc:title>O pai } \\
\text { daquele } \\
\text { menino</dc:title> }\end{array}$ & Obra \\
\hline Título Nacional & $\begin{array}{l}\text { 245_|b O pai } \\
\text { daquele menino } \\
\text { 246_| O pai } \\
\text { daquele menino }\end{array}$ & $\begin{array}{l}<\text { dc:title>O pai } \\
\text { daquele } \\
\text { menino</dc:title> }\end{array}$ & Expressão \\
\hline Produção & $\begin{array}{l}245 \_\mid c C T R-E C A- \\
\text { USP } \\
260 \_\mid b C T R-E C A- \\
\text { USP } \\
710 \_\mid C T R-E C A- \\
\text { USP }\end{array}$ & & $\begin{array}{l}\text { Relação Realizado } \\
\text { por }\end{array}$ \\
\hline Data de produção & $\begin{array}{l}008 \_\mid 2011 \\
260 \_\mid c 2011\end{array}$ & $\begin{array}{l}<\text { dc:date }>2011</ \\
\text { dc:date }>\end{array}$ & Obra \\
\hline Direção & $\begin{array}{l}\text { 245_|cperâ, } \\
\text { caroline } \\
700 \_\mid p e r a ̂, \text { caroline }\end{array}$ & $\begin{array}{l}<\text { name }>\text { with } \\
\text { type="personal" }\end{array}$ & $\begin{array}{l}\text { Relação Criado por } \\
\text { ou Realizado por }\end{array}$ \\
\hline Colaboração & 508_|ECA/USP & & $\begin{array}{l}\text { Relação Realizado } \\
\text { por }\end{array}$ \\
\hline Interprete & $\begin{array}{l}\text { 511_| Huzsar } \\
700 \_\mid H u z s a r\end{array}$ & $\begin{array}{l}<\text { name }>\text { with } \\
\text { type="personal" }\end{array}$ & Expressão \\
\hline Resumo & 520_l & & Expressão \\
\hline Assunto & $6 ? ?$ & $<$ abstract $>$ & \\
\hline Forma & 655_|Filme & & Obra o Expressão \\
\hline Gênero & 655_|Ficção & <genre> & Obra o Expressão \\
\hline Notas & $\begin{array}{l}\text { 500_TocadeBarroFil } \\
\text { mes } \\
501 \_\mid \\
\text {ocadeBarroFilmes } \\
518 \_\mid \\
\text {ocadeBarroFilmes }\end{array}$ & & Manifestação \\
\hline Distribuição & 260_| & & Manifestação \\
\hline
\end{tabular}

Fonte: Desenvolvido pela autora baseado em Macambyra (2009 apud FERREIRA, 2011). 
2. Ontologia representando as entidades e relacionamentos no Manual de Catalogação de Imagens em Movimento da FIAF:

a) Uso de RDF triplica: sujeito - predicado - objeto para todas as entidades e todos os seus relacionamentos

b) Uso de URI (Uniform Resource Identifier) para todas as entidades e todos os relacionamentos

c) Desenvolver linguagens processáveis por Máquinas e humanos, para uso em sistemas de catalogação

d) Interface: HTML para humanos no navegador da Web

e) Negociação de conteúdo: RDF, XML, JSON para sistemas para analisar e armazenar / exibir

3. Codificação LOD de vocabulários em Glossários Filmográficos e Técnicos, para uso em ontologia:

a) Codificar o FIAF Glossários para LOD:

- Filmográfico

- Técnico

b) Usar o SKOS (Simple Knowledge Organisation System) ou outro modelo para codificar vocabulários controlados como LOD. 


\section{Considerações finais e pesquisas futuras}

O objetivo desta pesquisa, de caráter exploratório e qualitativo, foi apresentar uma proposta de um conjunto de indicativos para preparar instrumentos de recuperação de filmes universitários da biblioteca da ECA dentro do contexto do linked data, entretanto, apesar dos esforços para definir um conjunto pertinente, foi constatado que a metodologia necessita ser ampliada e com maior prazo de execução, visto que o problema principal da pesquisa, que é a falta de campos e da exploração de campos e relacionamentos na recuperação de documento audiovisuais, necessita um maior aprofundamento de forma aplicada através de estudo de usuários, para entender como isso se dá na prática com a rotina da biblioteca, investigando quais entidades, campos e relacionamentos estão ocultos e quais procedimentos para resolver essa questão. Um segundo motivo para ampliar a metodologia é o fato de as pesquisas sobre o tema serem recentes, o que torna difícil encontrar pesquisas e resultados para o embasamento da pesquisa. Portanto, foram alcançados os objetivos específicos, sendo possível conhecer estudos recentes sobre representação da informação audiovisual e web semântica, entender quais são os instrumentos possíveis de serem aplicados nos catálogos de filmes da Biblioteca da ECA e apresentar um conjunto de indicadores gerais, que ainda não foram aplicados, desenvolvidos pela FIAF e futuramente pretende-se criar ambientes de buscas semânticas para o catálogo Trabalhos de conclusão de cursos de Audiovisual.

Neste sentido, foram realizados os seguintes passos: identificar instrumentos e metodologias de representação descritiva, temática através do estudo sobre os conceitos de representação descritiva e web semântica, estabelecendo paralelos e disjunções entre os tesauros, vocabulários da $\mathrm{Cl}$ e os tecnologias da Ciências da computação, de forma interdisciplinar, onde foi discutido questões referentes a migração do modelo conceitual FRBR e padrão MARC 21 para Linked Data;. Em seguida, ocorreu a analise de instrumentos para alinhar o manual de filmes da ECA e a base de dados aos princípios do Linked Open Data; foram discutidos os cenários de desenvolvimento dos instrumentos de representação descritiva frente a estruturação de dados em formato RDF e as possibilidades do linked data para o ambiente digital e realizado levantamento de iniciativas de criação de padrões de metadados, vocabulários, ontologias e modelos conceituais voltados ao domínio da descrição do linked data. Visto isso, a pesquisa buscou compreender como se relacionam o documento e o recurso audiovisual dentro do cenário de representação temática e descritiva de informação, para em seguida entender 
o contexto do documento audiovisual e o LD e analisou instrumentos e metodologias sobre os dados abertos vinculados (linked open data) em arquivos de filmes na perspectivas de pesquisas recentes internacionais conduzidas pela FIAF e Biblioteca do Congresso.

Os resultados mais importantes obtidos nesta pesquisa foram identificar quais caminhos estão sendo tomados para atualizar os catálogos de instituições para ambientes mais dinâmicos de forma a permitir a recuperação de informações de forma mais organizada na web, usando processamento de máquinas para obter buscas semânticas. E demonstrar que embora os instrumentos e os trabalhos dos profissionais locais da Biblioteca da ECA estejam em estágio avançado de desenvolvimento, no sentido de alinhar com o LD, pelo fato de não tratarem o acervo nem como especial e nem como de livros, além de anteciparem o uso do FRBR no manual (2009) antes que a próprio manual FIAF (2016), ainda existem lacunas em relação aos recursos audiovisuais e sua catalogação que precisam ser revistos, como demonstrou Van Malssen et al (2016), Gracy (2018), Domínguez-Delgado e López-Hernández, 2016), Grisoto (2016), (SIMIONATOet al., 2018). Esses problemas para representar campos, atributos e relações precisam ser discutidas, antes de serem aplicadas no acervo em pesquisas futuras para construir interfaces de busca que ajudem os usuários a encontrarem novas informações a partir de novas relações.

Desse modo, as instituições que usam catálogos baseados nas normas da FIAF ou com Manual de Catalogação próprios, como a Biblioteca da ECA são áreas onde o linked data pode atuar: a) criando ontologias a partir da lista de elementos do catálogo e conecta-los a ontologias externas; b) transformando vocabulários, Listas de Termos, Glossários em um conjunto de dados LOD mais formalizado de encontro as novas experiências dos usuários de arquivo de filmes no século XXI.

As relações possíveis de serem conectadas entre o documento fílmíco e um recurso externo da Biblioteca da ECA é conectá-lo a um conjunto de dados baseados em ontologias, os datasets que formam a nuvem do Linked Data, como por exemplo a Linked Movie Data Base, Geonames ${ }^{7}$ e Dbpedia ${ }^{8}$. Existem bases de dados online com domínios que podem ser relevantes para os usuários da Biblioteca da ECA como alunos,

\section{7}

http://www.geonames.org/

8

http://dbpedia.org/About 
pesquisadores e comunidade acadêmica, como bases voltas ao domínio da história Brasileira (antiga, moderna ou contemporânea) que se conectam à cinematografia brasileira, além de acervos no campo das Arte Visuais. Inclusive, a Biblioteca da ECA desenvolve o projeto de ontologia e web semântica para as produções do curso de artes visuais, intitulado Imagens interoperáveis: uso do VRA Core e da estrutura IIIF na construção de bibliotecas digitais, de autoria de Sarah Lorenzon Ferreira e Marina M. Macambyra (bibliotecárias da ECA) e da professora do CBD Vânia Maria Alves Lima.

É possível encontrar também instituições com acervo do campo da música ou ainda interligar a base de dados sobre partituras da ECA com o catálogo de filmes, além disso trabalhos de conclusão de curso de jornalismo podem ser conectados com as bases de dados da nuvem LOD com outros recursos de lugares, pessoas e assuntos, permitindo a navegação entre recursos, como o dataset da BBC News Labs, entre outros sobre jornalismo de dados.

Para pesquisas futuras pretende-se a construção de um ambiente digital para o acervo de filmes da biblioteca da ECA que permita aos usuários consultarem os links (conexões) existentes entre recursos audiovisuais do acervo e datasets da nuvem do linked open data, a partir de informações referentes a lugares, pessoas, termo, assunto, local, base de dados de filmes, entre outras relações que serão investigadas no desenvolvimento da pesquisa, a construção do ambiente será baseado nos princípios Linked Open Data e SPARQL como ferramentas para localização dos dados. As obras do acervo serão anotados semanticamente com metadados semiestruturados inteligíveis por máquinas, para que agentes de software auxiliem nas tarefas de busca, integração e processamentos dos filmes, estabelecendo uma base de conhecimento linked data de informação audiovisual, fazendo uso do padrão de dados semiestruturados Resource Description Framework (RDF) e o uso de ontologias para representação de domínios de conhecimento. Para isso será feito um estudo de usuário para definir quais são os possíveis interesses e como a pesquisa pode auxiliar na interação dos usuários do acervo e suas relações com o manual de catalogação da ECA, com os demais catálogos de filmes da biblioteca, analisando o conteúdo dos documentos e os registros da base de dados CENA, para isso será desenvolvido questionários com alunos e professores que utilizam a base de dados e os materiais do acervo. 


\section{Referências Bibliográficas}

AGANETTE, Elisângela Cristina; TEIXEIRA, Livia Marangon Duffles; AGANETTE, Karina de Jesus Pinto. A representação descritiva nas perspectivas do século XXI um estudo evolutivo dos modelos conceituais. Encontros Bibli: revista eletrônica de biblioteconomia e ciência da informação, Florianópolis, v. 22, n. 50, p. 176-187, set. 2017. ISSN 1518-2924. Disponível em:

<https://periodicos.ufsc.br/index.php/eb/article/view/1518-2924.2017v22n50p176>. Acesso em: 23 set. 2018.

ALMEIDA, Maria Christina Barbosa de - «Bibliotecas, Arquivos e Museus:

convergências». In Revista Conhecimento em Ação, Rio de Janeiro, v. 1, nº 1, jan/jun, 2006, pp.162-185

ALVARENGA, L. Representação do conhecimento na perspectiva da Ciência da Informação em tempo e espaço digitais. Encontros Bibli, v. 8, p. 18-40, 2003.

ARAKAKI, Felipe Augusto et al. BIBFRAME: tendência para a representação bibliográfica na web. RBBD. Revista Brasileira de Biblioteconomia e Documentação, São Paulo, v. 13, p. 2231-2249, dez. 2017. ISSN 1980-6949. Disponível em: <https://rbbd.febab.org.br/rbbd/ article/view/995/1030>. Acesso em: 29 set. 2018.

BARRETO, Juliano Serra. Desafios e avanços na recuperação automática da informação audiovisual. Ciência da Informação, Brasília, v. 36, n. 3, p. 17-28, set./dez. 2007.

BERMĖS, E. Enabling your catalogue for the semantic web. In: CHAMBERS, Sally (Ed.). Catalogue 2.0: the future of library catalogue. Chicago: NealSchuman, 2013. p. 117142.

BERNERS-LEE, T. Linked data. 2006.

BERNERS-LEE, T.; HENDLER, J.; LASSILA, O. The semantic web. Scientific American, London, v. 284, n. 5, p. 28-37, 2001.

BOCCATO, V. R. C.; RAMALHO, R. A. S.; FUJITA, M. S. L. A contribuição dos tesauros na construção de ontologias como instrumento de organização e recuperação da informação em ambientes digitais. In: García Marco, F. J. (Ed.). Avances y perspectivas en sistemas de información y documentación - IBERSID, 2008. Zaragoza: Universidad de Zaragoza, 2008. p. 199-209.

BUCKLAND, Michel. Information as thing. Journal of American Society of Information Science. v.42, n.5, 1991. p.351-360.

CATARINO; M.E.; CERVANTES, B.M.N.; SOUZA, T.B. O uso do Resource Description Framework na organização da informação. IN: ENCONTRO NACIONAL DE PESQUISA EM CIÊNCIA DA INFORMAÇÃO, 14., Florianópolis. Anais... Florianópolis : ANCIB, UFSC, 2013.

CATARINO, M.E.; BRÍGIDA MARIA, N.C.; ILZA ANDRADE, D.A. A representação temática no contexto da web semântica. Informação \& Sociedade, João Pessoa, v. 25, n. 32015 .

DOMíNGUEZ-DELGADO, R; LÓPEZ HERNÁNDEZ, M.-Á. (2017). Film content analysis on FIAF cataloguing rules and CEN metadata standards. In S. Erdelez \& N.K. 
Agarwal (Eds.), Proceedings of the Association for Information Science and Technology (pp. 655-657.) Hoboken, NJ: Wiley. https://doi.org/10.1002/pra2.2017.14505401104

FAIRBAIRN, N.; PIMPINELLI, M.A; ROSS, T. Moving Image Cataloguing Manual. FIAF, v.1, p.1-260, 2016.

FERREIRA, S.L. Catalogación de películas de la Biblioteca de la ECA/USP:

Perspectiva para el uso de los FRBR y RDA. Vi Encuentro De Catalogación Y Metadatos. p.73-85, set. 2011. Disponível em:

http://www3.eca.usp.br/sites/default/files/form/biblioteca/acervo/producao-academica/ 002838167.pdf. Acesso em : 13 jul. 2018

FIACCARINI, A; BIESBROUCK, B; MACCONNACHIE, S. Extending the FIAF Moving Image Cataloguing Manual and FIAF Glossaries using Linked Open Data. Paper da FIAF Catologuing and Documentation Comission, jul. 2017.

GIL, A.C. Como elaborar projetos de pesquisa. 4 ed. - São Paulo: Atlas, 2002

GIUSTI SERRA, Liliana, SANTARÉM SEGUNDO, José Eduardo. O catálogo da biblioteca e o linked data. Periódico Em Questão, Mai. Ago. 2018. Disponível em: <http://www.redalyc.org/articulo.oa?id=465650858009> ISSN 1807-8893. Acesso em: 21 de set. 2018.

GRACY, K.F. Enriching and enhancing moving images with Linked Data. Journal of Documentation, Bradford, v. 74, n. 2, p. 354-371, 2018.

GRISOTO, A.P. Um estudo acerca dos recursos audiovisuais no contexto do Linked Data. Dissertação (Mestrado em Ciências da Informação)- UNESP, Marilia, 2016.

LYONS, B.; VAN MALSSEN, K. (2016), "BIBFRAME AV assessment: technical, structural, and preservation metadata", estudo conduzido pela Library of Congress, AV Preserve, New York, NY. Disponível em: <www.loc.gov/bibframe/docs/pdf/bf-avtechstudy01-04-2016.pdf>. Acesso em: 12 mar. 2017.

MACAMBYRA, Marina. Manual de catalogação de filmes da Biblioteca da ECA. São Paulo: Serviço de Biblioteca e Documentação/ECA/USP, 2009. 74 p. Disponível em : http://www.rebeca.eca.usp.br/Manuais/Manual_de_catalogacao_de_filmes.pdf. Acesso em: abril. 2018

MACAMBYRA, Marina. Uma metodologia para tratamento de documentos audiovisuais. In: CONGRESSO BRASILEIRO DE CIÊNCIAS DA COMUNICAÇÃO, 24, 2001, Campo Grande. Anais . São Paulo: Sociedade Brasileira de Estudos Interdisciplinares.

MARCONDES, C. H. Interoperabilidade entre acervos digitais de arquivos, bibliotecas e museus: potencialidades das tecnologias de dados abertos interligados. Perspectivas em Ciência da Informação, v. 21, n. 2, p. 61-83, 2016.

MARCONDES, C. H. "Linked data" e interoperabilidade entre arquivos, bibliotecas e museus na web. Niterói: PROPi/UFF, 2012. (Projeto de Iniciação Científica submetido e aprovado pelo Programa Institucional de Bolsas de Iniciação Científica PIBIC - UFF 2012).

MAIMONE, G. D.; SILVEIRA, N. C.; TÁLAMO, M. F. G. M. Reflexões acerca das relações entre a Representação Temática e Descritiva. Informaçao \& Sociedade: estudos, João Pessoa, v.21, n.1, p. 27-35, jan./abr. 2011. Disponível em: <http:// www.ies.ufpb.br/ojs2/index.php/ies/article/ view/7367/5596>. Acesso em: 15 nov. 2012. 
MARCUM, D. A bibliographic framework for the digital age. 2011. Disponível em: https://www.loc.gov/bibframe/news/framework-103111.html.

MEY, Eliane Serrão Alves; MORENO, Fernada. Desafios do ensino de catalogação no Brasil. In: ENCONTRO NACIONAL DE CATALOGADORES, 1., 2012, Rio de Janeiro; ENCONTRO DE ESTUDOS E PESQUISAS EM CATALOGAÇÃO, 3., 2012, Rio de Janeiro. Disponível em: < http://pt.scribd.com/doc/109279226/Desafios-do-ensino-decatalogacao-no-Brasil>. Acesso em: 8 set. 2013.

MOSTAFA, Solange Puntel; SEGUNDO, José Eduardo Santarém; SABBAG, Deise Maria Antonio. Descrição bibliográfica na era da web semântica: por uma nova noção de documento. Informação e Sociedade: Estudos, João Pessoa, v. 26, n. 2, p. 25-35, 2016. Disponível em: < http://www.ies.ufpb.br/ojs/index.php/ies/article/view/29354/16194 >. Acesso em: 25. jul. 2017

ORTEGA, C.D. Do princípio monográfico à unidade documentária: exploração dos fundamentos da catalogação. Liinc em Revista, v.7, n.1, p.43-60, 2011.

PAULHEIM, Heiko. Knowledge Graph Refinement: A Survey of Approaches and Evaluation Methods. Semantic Web Journal, p. 1-23, 2017. Disponível em: http://www.semantic-web-journal.net/content/knowledge-graph-refinement-surveyapproaches-and-evaluation-methods. Acesso em: 26. out. 2018.

RAMALHO, Rogério Aparecido Sá. Bibframe: modelo de dados interligados para bibliotecas. Informação \& Informação, [S.I.], v. 21, n. 2, p. 292-306, dez. 2016. ISSN 1981-8920. Disponível em:

<http://www.uel.br/revistas/uel/index.php/informacao/article/view/26425>. Acesso em: 21 set. 2018. doi:http://dx.doi.org/10.5433/1981-8920.2016v21n2p292.

RASMUSSEN PENNINGTON, D. Demystifying Linked Data: are you ready for what's next?. CILIP Update, London, n. Jul./Aug., p. 34-36, 2016.

ROZSA, V.; MOISÉS, L.D.; NHACUONGUE, J.A. Linked Open Data no contexto acadêmico: identificação e análise de vocabulários utilizados na academia e na pesquisa científica. Brazilian Journal of Information Science, Marilia, v. 11, n. 32017.

SILVA, D. L. Ontologias para representação de documentos multimídia: análise e modelagem. Tese de Doutorado apresentada ao Programa de Pós-Graduação em Ciência da Informação da Escola de Ciência da Informação da Universidade Federal de Minas Gerais. 2014.

SIMIONATO, Ana Carolina et al. Audiovisuais e Linked data: um estudo das bases DBpedia e LMDB. Periódico Em Questão, v. 24, p.297-315, set. dez. 2018. Disponível em: https://seer.ufrgs.br/EmQuestao/article/view/78206/48784. Acesso em: 29 out. 2018.

SMIT, J. W. O documento audiovisual ou a proximidade entre as 3 Marias. Revista Brasileira de Biblioteconomia e Documentação, v. 26, n. 1/2, p. 81-85, 1993.

SMIT, J. A informação na Ciência da Informação. InCID: R. Ci. Inf. e Doc., Ribeirão Preto, v. 3, n.2, p. 84-101, jul./dez. 2012.

SOUZA, Elisabete Gonçalves de; BEZERRA, Darlene Alves. Os Functional Requirements for Bibliographic Records no contexto da Web Semântica: as contribuições de Paul Otlet. Transinformação, Campinas, v. 28, n. 2, p. 143-157, Ag. 2016. Disponível em: <http://www.scielo.br/scielo.php? 
script=sci_arttext\&pid=S010337862016000200143\&Ing=en\&nrm=iso >. Acesso em: 23 Sept. 2018.

KOBASHI, Nair Yumiko; FERNANDES, Joliza Chagas. Pragmática lingüística e organização da informação. In: ENCONTRO NACIONAL DE PESQUISA EM CIÊNCIA DA INFORMAÇÃO, 2009, João Pessoa. Anais... João Pessoa: PPGCI/UFPB, 2009.

VAN MALSSEN, K. "BIBFRAME AV modeling study: defining a flexible model for description of audiovisual resources". AV Preserve, New York, NY, 2014. Disponível em: www.loc.gov/bibframe/docs/pdf/bibframe-avmodelingstudy-may15-2014.pdf. Acesso em 19 agost. 2017).

VAN MALSSEN, K. "The FIAF Moving Image Cataloguing Manual”. The Journal of Film Preservation, v. 96, 2017. 
ANEXOS

\begin{tabular}{|c|c|}
\hline Campo MARC & Campo Dublin Core \\
\hline 035_9(DLC)76076436 & <de:identifier $>$ (DLC)76076436 /de.identifier \\
\hline 1002_laMachado de Assis & $\langle$ de:creator $>$ Machado de Assis $</$ de:creator $>$ \\
\hline 245_laDom Casmurro & $\langle$ dc:title $>$ Dom Casmurro $<$ dc:title $>$ \\
\hline $260 \_\mid$aSăo Paulo & \\
\hline
\end{tabular}

Fonte: Marcondes $(2012, p$.

\begin{tabular}{|c|c|c|}
\hline Base CENA & MARC21 & FRBR \\
\hline Titulo Original & $245 \mathrm{a}, 245 \mathrm{~b}$ & Obra \\
\hline E1Tínulo Nacional & $245 b$ e 246 & Expresíse \\
\hline Pais de Produccica & $257 \mathrm{e} 260 \mathrm{a}$ ()) & Otra \\
\hline $\begin{array}{l}\text { Fecha de } \\
\text { Producción }\end{array}$ & 008 e $260 c$ & Otra \\
\hline Otras facturs & 008 e 260 c & $\begin{array}{l}\text { Obra - Expresión- } \\
\text { Manifatacican - fiemen }\end{array}$ \\
\hline Drescción & $245 c=700$ & $\begin{array}{l}\text { Relacóin Cresala per } \\
\text { o Realizada porf }\end{array}$ \\
\hline $\begin{array}{l}\text { Orros autoroces } \\
\text { Prisicipales }\end{array}$ & 245 c 700 & $\begin{array}{l}\text { Relación Creadh pero o } \\
\text { Realizsdo por }\end{array}$ \\
\hline Productor & $245 \mathrm{c}, 260 \mathrm{~b}$ e 710 & Relarción Realizado pur \\
\hline $\begin{array}{l}\text { Colibbaración ea } \\
\text { la producrion }\end{array}$ & 508 & Relación Realizado poc \\
\hline Productor ascoinso & 508 & Relación Realizando po \\
\hline Whomes & 041 e 546 & Expresion \\
\hline Vearúín & 250 & Exprecíion \\
\hline $\begin{array}{l}\text { El directar del } \\
\text { Equipo }\end{array}$ & $245 c, 508,700$ & Exyresión \\
\hline Intedreters & $511 \mathrm{e} 700$ & Expresiogo \\
\hline
\end{tabular}

Fonte: Macambyra(2009, p.53)

\begin{tabular}{|c|c|c|}
\hline $\begin{array}{l}\text { Trabajo en que } \\
\text { se basó la pelicula }\end{array}$ & 500 & Relación Obra la Obra \\
\hline \multicolumn{3}{|l|}{ Descripción fisica } \\
\hline $\begin{array}{l}\text { Material } \\
\text { Número de copias }\end{array}$ & $\begin{array}{l}300 \\
300 \text { e } 538\end{array}$ & $\begin{array}{l}\text { Manifestación } \\
\text { Manifestación }\end{array}$ \\
\hline $\begin{array}{l}\text { Calibre, sistema y } \\
\text { de color estándar }\end{array}$ & 300 & Manifestación \\
\hline Cantidad de material & 300 & Obra o Manifestación \\
\hline $\begin{array}{l}\text { Caracteristicas } \\
\text { del somido }\end{array}$ & 300 & Expresión \\
\hline $\begin{array}{l}\text { Caracteristicas } \\
\text { de color } \\
\text { Longitud } \\
\text { Region }\end{array}$ & 300 e 538 & \\
\hline $\begin{array}{l}\text { Formato de pantalla } \\
\text { (sólo para DVD) }\end{array}$ & 500 & Manifestación \\
\hline Distribución & 260 & Manifestación \\
\hline Serie & 490 & Manifestación \\
\hline Eventos y premios & 500 & Expresión \\
\hline Notas & $500,501,518$ & Manifestación \\
\hline Los extras del DVD & 500 & $\begin{array}{l}\text { Las relaciones entre las } \\
\text { entidades del Grupo } 1\end{array}$ \\
\hline Referencia & & $\begin{array}{l}\text { Las relaciones entre las } \\
\text { entidades del Grupo } 1\end{array}$ \\
\hline Resumen & 520 & Expresión \\
\hline Tema & $6 ?$ & Entidades del Grupo 3 \\
\hline Género $y$ la forma & 655 & Obra o Expresión \\
\hline
\end{tabular}

Figura 1 - Resumen de los campos

Fuente: Macambyra (2009, p.53). 